\title{
At the Intersection of Public Policy and Private Process: Court-Ordered Mediation and the Remedial Process in School Funding Litigation
}

\author{
MOLLY TOWNES O’BRIEN*
}

\begin{abstract}
I begin with caution. Each human being is unique, as is each society. It follows logically, then, that no two conflicts are the same. There is no magic formula which, once discovered, can be used to end all conflicts. ${ }^{1}$
\end{abstract}

\section{INTRODUCTION}

The story of school finance reform has been, as Mark Yudof, President of the University of Minnesota, once wrote, "like a Russian novel: it's long, tedious, and everybody dies in the end." 2 When the Supreme Court of Ohio issued its order referring DeRolph v. State ${ }^{3}$ to mediation, the court hoped, perhaps, to transform an otherwise dreary opus into a story with a happy ending. The school finance case presented complex legal, political, public policy, and administrative issues and had dragged on for a decade. ${ }^{4}$ The Supreme Court had declared the constitutional rights and obligations of the parties almost five years earlier, ${ }^{5}$ but implementation of a remedy for the violation of state constitutional rights remained elusive. ${ }^{6}$ The court deemed

* Associate Professor of Law, University of Akron School of Law. I am deeply indebted to professors Brant Lee, E. Stewart Moritz, Elizabeth Reilly and Tracy Thomas for their comments on earlier drafts of this article and for their help and support with the writing process. Thank you also to Andrea Doneff, Vice President, Resolution Resources Corporation, for her insightful comments and editorial help.

${ }^{1}$ George J. Mitchell, 8 DisP. RESOL. MaG., Spring 2002, at 4, 6 (qualifying his response to requests that he compare the prospects for conflict resolution in Northern Ireland and the Middle East).

${ }^{2}$ Mark G. Yudof, School Finance Reform in Texas: The Edgewood Saga, 28 HARv. J. ON LEGIS. 499, 499 (1991).

${ }^{3}$ DeRolph v. State, 758 N.E. 2d 1113 (Ohio 2001) (DeRolph Mediation).

${ }^{4} \mathrm{Id}$. at 1116.

${ }^{5}$ DeRolph v. State, 677 N.E.2d 733, 737 (Ohio 1997) (DeRolph I) (holding that the public school funding system fails to meet the Ohio Constitution's requirement that the legislature provide for a "thorough and efficient system of common schools").

${ }^{6}$ See generally DeRolph v. State, 754 N.E.2d 1184 (Ohio 2001) (DeRolph III) (discussing the efforts by the legislature to cure constitutional infirmity of the school 
the case to be "the most difficult challenge" it had faced in all the years the case had been pending. ${ }^{7}$ Here, perhaps, was an opportunity to rewrite the school finance story and, at the same time, demonstrate that court-ordered mediation ought to be viewed not merely as a viable alternative for the resolution of private disputes, but more importantly as a valuable remedial tool in complex public institutional reform litigation. ${ }^{8}$

Scholars have long recognized that the public law litigation ${ }^{9}$ process is "suffused and intermixed with negotiating and mediating processes at every point." 10 Recently, scholars seeking to build a model for an effective remedial process in public disputes have suggested deliberative processes, multi-lateral decision-making, consensus building, and community dialogue. ${ }^{11}$ In DeRolph, it seemed there was a prominent opportunity to put ADR to its toughest test. Could court-ordered mediation provide the bridge between legal wrong and judicial remedy in a school finance reform case?

funding system and finding those efforts insufficient), vacated by DeRolph v. State, 780 N.E.2d 529 (2002) (DeRolph IV); see also infra text accompanying notes 111-35

${ }^{7}$ DeRolph Mediation, 758 N.E.2d at 1116.

${ }^{8}$ Institutional reform litigation typically requires the courts to scrutinize the operation of large public institutions. Theodore Eisenberg and Stephen C. Yeazell, The Ordinary and the Extraordinary in Institutional Litigation, 93 HARV. L. REV. 465, 467 n.6 (1980). Examples of types of cases generally classified as "institutional" or "structural" include challenges to conditions in prison and in mental hospitals and litigation involving voting districts and school desegregation. Id. at 467-68 n.6. See also Susan P. Sturm, A Normative Theory of Public Law Remedies, 79 GeO. L.J. 1355, 1357 n.1 (1991).

${ }^{9}$ For purposes of this article, I use the terms "public law litigation" and "institutional reform litigation" interchangeably. Citations to more refined definitions of the terms used by other scholars may be found in Sturm, supra note 8, at 1357 n.1.

${ }^{10}$ Abram Chayes, The Role of the Judge in Public Law Litigation, 89 HARV. L. REV. 1281, 1284 (1976). See also Margo Schlanger, Beyond the Hero Judge: Institutional Reform Litigation as Litigation, $97 \mathrm{MICH}$. L. REV. 1994, 1999-2000 (1999) (arguing that negotiated settlement is the primary source of judgment in prison reform litigation); Marc Galanter, Worlds of Deals: Using Negotiation to Teach about Legal Process, 34 J. LEGAL EDUC. 268, 268 (1984) (coining the term "litigotiation" to describe a process in which litigation is the necessary context for negotiation).

${ }^{11}$ Michael A. Rebell \& Robert L. Hughes, Schools, Communities, and the Courts: A Dialogic Approach to Education Reform, 14 YALE L. \& POL'Y ReV. 99, 113-19 (1996) (proposing a community engagement dialogic model for resolving conflict related to school reform); Sturm, supra note 8, at 1427-34 (proposing a deliberative model of public remedial decision making). In addition, in practice, courts and practitioners have turned increasingly to alternative dispute resolution mechanisms to resolve public disputes. Rebell \& Huges, supra at 117 (listing school-based controversies that used alternative dispute resolution techniques in recent years). 


\section{COURT-ORDERED MEDIATION IN SCHOOL FUNDING}

Would mediation provide a process for the improved accomplishment of justice? ${ }^{12}$

Within a few short months of the court's order requiring mediation, the answer to these questions appeared to be a resounding "No!" On March 21, 2002, the mediator reported that the DeRolph mediation had failed. ${ }^{13}$ Any hope that the experiment would produce a happy ending to the school finance litigation or would reflect well on the mediation process was dashed. Rather than a shining example of the potential of court-ordered mediation, DeRolph would stand as a very public example of the failure of the process.

This article will examine the DeRolph case, particularly the court's decision to turn to mediation, and will suggest that the case should serve as a cautionary tale, with lessons for future courts in how to structure courtordered mediation. ${ }^{14}$ This exploration of the DeRolph mediation is based in part on discussions with experienced and talented mediators. ${ }^{15}$ It is intended as the beginning of what I hope will be a continued scholarly discussion of the potential for court-ordered mediation to provide procedural justice in the remedial phase of institutional reform litigation. ${ }^{16}$ The article begins (Part II) by sketching out some of the difficulties that courts encounter when designing a remedy in a school finance case and some of the reasons why, at least in the abstract, a mediation process may assist the parties and the

12 Professor Menkel-Meadow points out that the accomplishment of justice has both substantive and procedural aspects. Carrie Menkel-Meadow, Practicing "In the Interests of Justice" in the Twenty-first Century: Pursuing Peace as Justice, 70 FORDHAM L. REv. 1761,1763 (2002) (noting that the process by which we seek justice is a component of its achievement).

${ }^{13}$ Final report of Howard Bellman, at http://www.sconet.state.oh.us/derolph/ bellman3-21.pdf (last visited Nov. 13, 2002).

${ }^{14}$ See infra Part IV, in which I attempt to identify the reasons for the failure of the DeRolph mediation and suggest guidelines for future court-ordered mediation in school finance cases.

15 I would specifically like to acknowledge and thank Ansley Barton, Howard Bellman, Harold Clarke, Andrea Doneff, Mori Irvine, Amy Totenberg, and Doug Yarn for giving me the benefit of their extensive knowledge and experience in mediation. Many of the ideas presented in this article flow from the discussions I have had over the years (and recently, of course) with these highly skilled and exceptionally thoughtful trailblazers in alternative dispute resolution.

16 School finance reform litigation generally takes place in at least two phases, a liability phase and a remedy phase. In school finance reform litigation, "[t]he remedial process begins when the court finds that the defendants are liable for violating the plaintiffs' rights and must remedy the harm caused by their unlawful conduct." Sturm, supra note 8 , at 1360 . 
court. ${ }^{17}$ Next, in Part III the article provides a brief history of the DeRolph litigation, placing the abstract concepts against the concrete details of a particular case. ${ }^{18}$ Part IV explores some possible reasons for the failure of the DeRolph mediation and suggests what might have been done to create a better possibility for success. ${ }^{19}$

In spite of the failure of the DeRolph mediation, I posit that the mediation process may play a productive role in the future of school finance cases. Court-ordered mediation may permit the re-structuring of the remedial process in a way that that addresses minority rights which often are lost or minimized in the traditional legislative process. ${ }^{20}$ Further, a participatory mediation process holds promise for achieving remedial results in a school finance case that are both educationally viable and politically sustainable. Mediation may open new avenues for the resolution of litigation at the intersection of private process and public policy.

Indeed, there is a potential for voluntary or court-ordered mediation to play a role in the future of the DeRolph case itself. At this writing, implementation of a remedy for the constitutional violations identified by the Court remains elusive. ${ }^{21}$ As the parties continue to search for a way to provide an educational system that meets Ohio constitutional mandates, they may once again turn to mediation. This article represents an effort to learn from past failure and to plan for future success in school finance mediation and other public law litigation.

17 See text and accompanying notes infra pp. 395-405.

18 See text and accompanying notes infra pp. 405-17.

19 See text and accompanying notes infra pp. 417-35.

${ }^{20}$ For a provocative discussion of a more radically re-structured democratic process, see, Michael C. Dorf \& Charles F. Sabel, A Constitution of Democratic Experimentalism, 98 COLUM. L. REV. 267, 314-39 (1998), which describes a redefined democratic selfgovernment, "directly deliberative polyarchy," involving collective problem-solving by citizens and groups suited to local diversity. Id. at 315. Court-ordered mediation of institutional reform may, to a limited extent, participate in the kind of democratic experimentalism envisioned by Professors Dorf and Sabel.

${ }^{21}$ Following the failure of the mediation process described in this article, the Court granted the State's motion to reconsider DeRolph III and reinstated DeRolph I and II as the law of the case. See generally DeRolph IV, 2002 Ohio Lexis 3025; see also infra text accompanying notes $237-44$. 


\section{WHY CONSIDER MEDIATION IN SCHOOL FINANCE LiTIGATION?}

\section{A. The Particular Remedial Difficulty of School Finance Litigation}

The remedial process in all institutional or structural reform litigation is fraught with theoretical and practical difficulty, ${ }^{22}$ but it has been particularly prolonged and troubled in school finance litigation. ${ }^{23}$ This is so not only because of the substantive and procedural complexity of school funding reform litigation, but also because of its broad implications for society's governance, fisc, and future.

Education is widely perceived to be the engine of the economy, the safeguard of liberty, and the key to meritocracy. As the Supreme Court pointed out in Brown v. Board of Education: "In these days, it is doubtful that any child may reasonably be expected to succeed in life if he is denied the opportunity of an education." 24 Similarly, a representative democracy cannot be reasonably expected to succeed without an educated citizenry. ${ }^{25}$ Education is expected not only to produce citizens capable of selfgovernment and to encourage cohesion among diverse peoples, ${ }^{26}$ but it is also expected to be "the great equalizer of the conditions of men-the

22 Susan Sturm, Resolving the Remedial Dilemma: Strategies of Judicial Intervention in Prisons, 138 U. PA. L. REV. 805, 807-09 (discussing the problems facing judges in devising remedial orders in prison reform litigation); GERALD N. ROSENBERG, THE Hollow Hope: Can Courts Bring About Social Change? (1991) (suggesting that courts lack the capacity to bring about meaningful social or educational change). Many scholars have debated the efficacy and authority of the courts in institutional reform. William S. Koski \& Henry M. Levin, Twenty-Five Years after Rodriguez: What Have We Learned? 102 TCHR[s]. C. REC. 480, 496 (2000) (citing a body of literature, "much of it skeptical of judicial efficacy," relating to judicial policy making process in institutional reform cases).

${ }^{23}$ School finance reform cases in New Jersey and Texas provide vivid examples of troubled remedial processes. Litigation spanning three decades and still on-going in New Jersey is chronicled in Margaret E. Goertz, Steady Work: The Courts and Reform in New Jersey, in STRATEGIES FOR SCHOOL EQUITY 101, 107-13 (Marilyn J. Gittell ed., 1998). See also Yudof, supra note 2, at 499-500 (analyzing decades of school finance reform in Texas.)

${ }^{24}$ Brown v. Bd. of Educ., 347 U.S. 483, 493 (1954).

${ }^{25}$ As Thomas Jefferson wrote, "If a nation expects to be ignorant and free, in a state of civilization, it expects what never was and never will be." LAWRENCE A. CREMIN, THE AMERICAN COMMON SCHOOL 29 (1951) (quoting Thomas Jefferson).

${ }^{26}$ Carl F. Kaestle, Pillars of the Republic 6-7 (Eric Foner ed., 1983) (discussing the views of Benjamin Rush and Thomas Jefferson). 
balance wheel of the social machinery." 27 Theoretically, ${ }^{28}$ and to some extent demonstrably, ${ }^{29}$ education is the vehicle of social mobility in modern American society.

State constitutions recognize the importance of education and charge state legislatures with providing for a system of public schools. ${ }^{30}$ Although there are deep divisions of opinion among scholars, advocates, and jurists on questions of curriculum, accountability, discipline, etc., there is broad consensus that each child should have an opportunity to an adequate ${ }^{31}$ education at state expense. ${ }^{32}$ In spite of this broad consensus, however,

27 Horace Mann, 10th Annual Report, in AMERICAN Public SCHOOL Law 26 (Kern Alexander \& M. David Alexander eds., 1998). Horace Mann believed that if education could be "equably diffused, it [would] draw property after it, by the strongest of all attractions; for such a thing never did happen, and never can happen, as that an intelligent and practical body of men should be permanently poor ...." Id. at 26 .

$28 \mathrm{Id}$. at 25.

29 JOEL SPRING, AMERICAN EdUCATION, 76-105 (9th ed. 2000) (analyzing the economic effects of educational opportunity and attainment); see also SOUTHERN Education Foundation, MiLes to Go: ARKANSAS (2002) (one of a series of reports providing data that links educational opportunity and attainment to economic advancement).

${ }^{30}$ Allen W. Hubsch, The Emerging Right to Education Under State Constitutional Law, 65 TEMP. L. REV. 1325 app. at 1343-48 (1992) (collection of state constitutional provisions); see also KeRn AleXANDER \& DAvid M. AleXANDER, AmeriCAN PubliC SCHOOL LAW, 30-32 (4th ed. 1998) (summarizing the underlying principles that are common to most state constitutional educational provisions and summarizing the differences among several categories of provisions); William E. Thro, The Role of Language of the State Education Clauses in School Finance Litigation, 79 EDUC. L. REP. 19, 19 n.1 (1993) (collection of state constitutional provisions).

31 Of course, the content of an "adequate" education remains highly controversial. Even the term "adequate education" is, itself, a term laden with history. The quest for an "adequate" education, which is the goal of the current "wave" of educational finance reform litigation, was a strategic choice pursued by education advocates in the wake of the failure of lawsuits seeking "equality" or "equity" in education. William H. Clune, The Shift from Equity to Adequacy in School Finance, 8 J. OF EDUC. POL'Y 376 (1994) (describing adequacy and equity theories in school finance); Michael Heise, Equal Educational Opportunity, Hollow Victories, and the Demise of School Finance Equity Theory: An Empirical Perspective and Alternative Explanation, 32 GA. L. REv. 543, 545-46 (1998) (describing successive strategy choices in educational finance litigation).

32 Even the free market economist, Milton Friedman, who suggested that governments might require a minimum level of education but require parents to pay for it, conceded that preservation of the public good requires public subsidy of education. Milton Friedman, The Role of Government in Education, in ECONOMICS AND THE PUBLIC INTEREST 125-27 (Robert A. Solo ed., 1955). But see MYRON LiEBERMAN, 
history demonstrates that democratic processes have failed to provide for the educational needs of every child, particularly those who are poor, who are members of minority groups, or who live in rural areas. ${ }^{33}$ The probable reasons for the failure of democratic processes to provide universally available, high quality education are complex and manifold, but certainly include localism, ${ }^{34}$ private pursuit of educational advantage, ${ }^{35}$ and children's

Privatization And EduCational Choice 303 (1989) (arguing that parents should pay for their children's education from their own income).

33 The continuing inequality and inadequacy of public schools for poor children, minority children, and children in some rural areas has been documented at trial, in scholarly studies, and in the popular media. See, e.g., DeRolph 1, 677 N.E.2d 733, 743-44 (Ohio 1997) (Trial revealed that some Ohio schools were contaminated by asbestos, carbon monoxide, sewage overflow, and kerosene fumes; schools in poor districts lacked heat and basic supplies). Particularly vivid depictions of the disparities in educational resources can be found in CHILDREN IN AMERICA's SCHOOLS: WITH BILL MOYERS, Saint/Hayden Co., South Carolina ETV and Nebraska ETV (1996). See generally JONATHAN KOZOL, SAVAGE INEQUALITIES (1991) (an in-depth look at the inequality of the school systems in New Jersey); JOHN D. OWEN, SCHOOL INEQUALITY AND THE WELFARE STATE (1974) (examining the financial inequalities present in American public school systems and asserting that decentralization of control of financing and middle class bias of bureaucracies have created and maintained a system of unequal treatment of poor and minority communities). For a history of school finance litigation in 44 states, see Michael Rebell, Education Adequacy, Democracy and the Courts, at $\mathrm{http}: / / \mathrm{www}$.accessednetwork.org/resources/EDUADEQ.PDF (last visited July 26, 2002).

34 Schooling has historically been viewed as a function of local governments. While local control may have some advantages in terms of efficiency and flexibility, local funding mechanisms have contributed significantly to inequity in school funding. Richard Briffault, Our Localism: Part I-The Structure Of Local Government Law, 90 CoLUM. L. REV. 1 (1990). Professor Briffault points out:

Localism reflects territorial economic and social inequalities and reinforces them with political power. Its benefits accrue primarily to a minority of affluent localities, to the detriment of other communities and to the system of local government as a whole. Moreover, localism is primarily centered on the affirmation of private values. Localist ideology and local political action tend not to build up public life, but rather contribute to the pervasive privatism that is the hallmark of contemporary American politics. Localism may be more of an obstacle to achieving social justice and the development of public life than a prescription for their attainment.

Id. at $1-2$.

${ }^{35}$ I have argued elsewhere that during the mid-twentieth century, as educational credentials became the currency of social mobility, and as the middle class sought to insulate their children from downward mobility, schools developed in response to the demands of parents who sought to give their children a competitive advantage. The continuing pursuit of individual educational advantage conflicts and competes with the public goal of providing universally available, high quality education. Molly Townes 
relative lack of political and economic power. ${ }^{36}$ In searching for a reason that our society continues to fail to meet children's needs, Professor Martha Minow suggests, "[p]erhaps because of our troubled heterogeneity, with historic racism and intergroup distrust, we do not view other people's children as ours in many important ways." 37

Whatever the reasons for the failure of democratic processes to provide fully and equally for all children's educational needs, during the past quarter century education advocates have repeatedly turned to the courts seeking to enforce educational rights defined in state constitutions: ${ }^{38}$ While educational equity or adequacy is the goal of school finance reform litigation, the chief target of such suits has traditionally been the system of taxing and allocating the resources that support public schools. The "classic" argument under girding school finance reform litigation is that over reliance on local property taxes to fund public schools results in well-funded schools in wealthy districts and poorly-funded schools in poor districts. ${ }^{39}$ Plaintiffs have argued that the funding system that creates such disparities is unconstitutional under state constitutional provisions that require state legislatures to provide, for example, an "efficient," "thorough," or "uniform" system of public schools. ${ }^{40}$ Seeking "equity" in school funding, plaintiffs have pursued equalization of "input measures, such as total educational and per-pupil spending levels." 41 Taxing and spending levels, however, are not the sole targets of school finance reform litigation. Recent school finance reform litigation advances a theory that "all children are entitled to an education of at least a certain quality and that more money is necessary to bring the worst school districts

O'Brien, Private School Tuition Vouchers and the Realities of Racial Politics, 64 TENN. L. REV. 359, 373-75 (1997).

36 Paul E. Peterson, An Immodest Proposal, DAEDalus, Fall 1992, at 151 (contrasting the success of the elderly in moving out of poverty and strengthening public programs to meet their financial and medical needs with the failure of children's advocates to achieve the same results); Martha Minow, What Ever Happened to Children's Rights?, 80 MINN. L. REV. 267, 295 (1995) (suggesting that the lack of a vote or another lobby may be one of the reasons for the failure of children's initiatives).

37 See Minow, supra note 36, at 295.

${ }^{38}$ Molly McUsic, The Use of Education Clauses in School Finance Reform Litigation, 28 HARV. J. ON LEGIS. 307, 310 (1991) (analyzing the success of state constitutional claims seeking reform of school financing).

${ }^{39}$ Mark G. Yudof, School Finance Reform: Don't Worry, Be Happy, 10 REv. LiTIG. 585, 585-86 (1991) (recapitulating the "classic" argument).

${ }^{40}$ See ALEXANDER \& ALEXANDER, supra note 27, at 30-32 (summarizing state constitutional provisions relating to school funding).

${ }^{41}$ Heise, supra note 31 , at 545. 


\section{COURT-ORDERED MEDIATION IN SCHOOL FUNDING}

up to the minimum level mandated by the state education clause."42 Although these lawsuits seek better resources, facilities and more funding, their focus is on equitable educational quality, or, on educational outputs, rather than on expenditure levels alone. ${ }^{43}$ Thus, remediation under a state constitution's educational clause may require an assessment of available educational resources, needs and goals, followed by the development and implementation of a plan for meeting those needs and achieving those goals.

Given the breathtaking scope of school finance reform litigation, it should come as no surprise that defining a remedy has been problematic in school finance reform litigation. More than twenty-five years of postRodriguez ${ }^{44}$ litigation in 44 states $^{45}$ has yielded ambiguous results and has led many to question the ability of the courts to bring about meaningful change in school finance. ${ }^{46}$ State courts, in turn, have repeatedly identified violations of state constitutional education requirements, ${ }^{47}$ but have frequently failed to provide an effective remedy. ${ }^{48}$

42 William E. Thro, Judicial Analysis During the Third Wave of School Finance Litigation: The Massachusetts Decision as a Model, 35 B.C. L. REV. 597, 603 (1994).

${ }^{43}$ Id. at 600-03. See also Heise, supra note 31, at 545-46.

44 In San Antonio Indep. Sch. Dist. v. Rodriguez, 411 U.S. 1 (1973), the Supreme Court held that funding disparities between school districts did not violate the 14th Amendment Equal Protection guarantee. After suffering defeat in the Rodriguez case, education advocates turned to state constitutional education clauses to pursue the goal of educational equity. Michael Rebell, Rodriguez Revisited: An Optimist's View, 1998 ANN. SURV. AM. L. 289, 292-93 (1998).

45 The Advocacy Center for Children's Educational Success with Standards (ACCESS) provides on-line updates of school finance litigation in forty-four states, at http://www.accessednetwork.org/statesmain.html (last visited Aug. 15, 2002). The website states that Hawaii, Indiana, Mississippi, Nevada, and Utah are the states without education finance litigation. Id.

${ }^{46}$ Heise, supra note 31, at 547 ("[E]ven successful school finance equity lawsuits do not appear to have altered centralization or spending levels in ways (or to the degree) most likely sought by litigants."); see also Note, Unfulfilled Promises: School Finance Remedies and State Courts, 104 HARV. L. REv. 1072, 1072 (1991) (arguing that legislative inertia and judicial deference to the legislature and executive contribute to the difficulty in securing a remedy in school finance reform cases). But see G. Alan Hickrod, et al., The Effect of Constitutional Litigation on Education Finance: A Preliminary Analysis, 18 J. EDUC. FIN. 180, 207-08 (1992) (suggesting that in states where courts found funding schemes unconstitutional, combined state and local per-pupil expenditures increased).

47 Violations of state constitutional education requirements were found in Alaska, Arizona, Arkansas, California, Connecticut, Idaho, Kansas, Kentucky, Massachusetts, Missouri, Montana, New Hampshire, New Jersey, New Mexico, New York, North Carolina, South Carolina, Tennessee, Texas, Vermont, Washington, West Virginia, and 
School finance reform litigation, as a species of public law litigation, ${ }^{49}$ faces particular remedial problems that are not present in the typical private suit that seeks damages or negative injunctive relief. ${ }^{50}$ Like other structural or institutional reform litigation, school finance reform litigation is "sprawling and amorphous," 51 affecting many parties who are not before the court, some of whom may have no entitlement to a remedy in the case at hand, but who may be in a position to thwart the eventual implementation of

Wyoming. See, e.g., Roosevelt Elementary Sch. Dist. v. Bishop, 877 P.2d 806, 808 (Ariz. 1994); Rose v. Council for Better Educ., Inc., 790 S.W.2d 186, 189 (Ky. 1989); Helena Elementary Sch. Dist. v. State, 769 P.2d 684, 685 (Mont. 1989), amended by 784 P.2d 412 (1990); Abbott ex rel. Abbott v. Burke, 575 A.2d 359, 363 (N.J. 1990); Brigham v. State, 692 A.2d 384, 386 (Vt. 1997); Seattle Sch. Dist. v. State, 585 P.2d 71, 77 (Wash. 1978); Pauley v. Kelly, 255 S.E.2d 859, 884 (W.Va. 1979). State courts that have upheld school financing systems against constitutional challenges include Alabama, Colorado, Florida, Georgia, Illinois, Louisiana, Maine, Maryland, Michigan, Minnesota, Oklahoma, Oregon, Pennsylvania, Rhode Island, Virginia, and Wisconsin. See, e.g., Lujan v. Colo. State Bd. of Educ., 649 P.2d 1005, 1011 (Colo. 1982); McDaniel v. Thomas, 285 S.E.2d 156, 168 (Ga. 1981); Thompson v. Engelking, 537 P.2d 635, 636 (Idaho 1975); Hornbeck v. Somerset County Bd. of Educ., 458 A.2d 758, 780 (Md. 1983); Skeen v. State, 505 N.W.2d 299, 320 (Minn. 1993); Bd. of Educ. v. Nyquist, 439 N.E.2d 359, 361 (N.Y. 1982), appeal dismissed for want of substantial federal question, 459 U.S. 1138 (1983); Fair Sch. Fin. Council of Okla., Inc. v. State, 746 P.2d 1135, 1137 (Okla. 1987); Olsen v. State, 554 P.2d 139, 143 (Or. 1976); Danson v. Casey, 399 A.2d 360 (Pa. 1979); Richland County v. Campbell, 364 S.E.2d 470, 472 (S.C. 1988); Scott v. Commonwealth, 443 S.E.2d 138, 142 (Va. 1994); Kukor v. Grover, 436 N.W.2d 568, 570 (Wis. 1989).

48 Heise, supra note 31, at 547 ("[E]ven successful school finance equity lawsuits do not appear to have altered centralization or spending levels in ways (or to the degree) most likely sought by litigants."); Rebell \& Hughes, supra note 11 , at 112 ("[C]ourt involvement rarely provides a fully satisfactory solution to complex educational controversies."). But see Hickrod, supa note 46, at 206-07 (noting that in states where courts found funding schemes unconstitutional, combined state and local per-pupil expenditures increased); Molly A. Hunter, All Eyes Forward: Public Engagement and Educational Reform in Kentucky, 28 J.L. \& EDUC. 485, 516 (1999) ("Kentucky has implemented a systemic package of curricular and governance reforms and tied them to funding reform. It has maintained an unusually strong commitment to equity in funding .... [T] The state of learning in Kentucky is improving.").

${ }^{49}$ See generally Chayes, supra note 10, at 1281-1304 (describing the characteristics of public law litigation in contrast to traditional bi-polar private law suits).

50 William H. Clune, New Answers to Hard Questions Posed by Rodriguez: Ending the Separation of School Finance and Educational Policy by Bridging the Gap Between Wrong and Remedy, 24 CONN. L. REV. 721, 723 (1992) (noting that devising a remedy in school finance reform cases requires enormous creativity).

51 Chayes, supra note 10 , at 1284. 
the court's order. ${ }^{52}$ Further complicating the remedial process, state constitutional norms provide only guidelines for the remedy rather than the specifics. ${ }^{53}$ While educational rights can be identified in principle, imbuing the rights with meaning in the real world requires an almost endless number of small decisions relating to public policy, educational philosophy, and economic management. ${ }^{54}$ Formulation of a remedy requires choices among a wide variety of possibilities. ${ }^{55}$ Further, the task of making choices among various remedial possibilities is made even more difficult by the constantly changing demographics of schools and the inconsistent ebb and flow of tax dollars available in a volatile economy. ${ }^{56}$ Moreover, outcomes, standards, and measures of success are highly contested and-even when they are agreed upon-fragile. ${ }^{57}$ The remedial fact-finding required to make reasoned choices in this situation is essentially forward-looking, requiring expertise and insight into the merits of various proposals for an on-going plan for the remediation of violations of norms defined in the state constitution. ${ }^{58}$

School finance litigation is, perhaps, even more problematic for the courts than other types of institutional reform litigation because the defendants include a co-equal branch of government, the state legislature, acting within the ambit of the legislature's traditionally acknowledged area

52 Sturm, supra note 8, at 1364-65; Paul Gewirtz, Remedies and Resistance, 92 YALE L.J. 585, 604 (1983) (noting that remedies in discrimination cases often impose substantial burdens on non-wrong doers).

53 Even when courts have endeavored to give specific content to the terms used in constitutional education clauses, the result still states principles in broad rather than fine detail. See, e.g., Rose v. Council for Better Edu., Inc., 790 S.W.2d 186, 205-06 (Ky. 1989) (defining an "efficient" system of common schools to have nine minimal essential characteristics, including being free to all children, being uniform across the state, providing an "adequate" education, etc.).

${ }^{54}$ See Yudof, supra note 39, at 588-97 (describing multiple options available to legislatures as they formulate plans to equalize school spending).

55 Id.; see also DeRolph III, 754 N.E.2d 1184, 1209-13 (Ohio 2001) (Douglas, J., concurring) (examining a range of options available to the court and to the legislature).

${ }^{56}$ For an excellent insight into the complexity of the problems facing school reformers, see John Charles Boger, Education's Perfect Storm? Racial Resegregation, High Stakes Testing \& School Inequities, 81 N.C. L. Rev. (forthcoming 2003).

${ }^{57}$ For a description of the fragility of remedies in school desegregation cases, see Amy Stuart Wells, No Accountability for Diversity: Standardized Tests and the Demise of Racially Mixed Schools, 81 N.C. L. Rev. (forthcoming 2003).

${ }^{58}$ But see Yudof, supra note 39 at 595-98 (noting the difficulty of predicting public response to and fiscal impact of legislative choices, and asserting that "horse-trading," rather than rational models governs legislative choice). 
of expertise. ${ }^{59}$ And school finance cases ask the court to address not just any taxing and spending issue, but the largest taxing and spending item on the legislative agenda. ${ }^{60}$ The enormous amount of money at stake puts school finance issues in competition with all other budget issues. Small changes required in school finance may create ripple effects throughout the state budget. Large changes may create a tidal wave that upsets important programs or that requires reform of the entire system of state taxation. ${ }^{61}$

Courts may also hesitate to enter into the remedial fray of school finance because implementation of rights to schooling necessarily depends on the cooperation of political actors who may be opposed to the goals of the court's order and who have the de facto power to delay, disrupt, or block its implementation. ${ }^{62}$ This raises not only theoretical jurisprudential concerns, but also practical concerns about the power and legitimacy of the court. ${ }^{63}$ Within the context of a state government, the court ultimately relies on the

${ }^{59}$ See, e.g., San Antonio Indep. Sch. Dist. v. Rodriguez, 411 U.S. 1, 41 (1973) ("[W]e continue to acknowledge that the Justices of this Court lack both the expertise and the familiarity with local problems so necessary in the making of wise decisions with respect to the raising and disposition of public revenues."). Note that the Ohio Constitution vests the judicial power of the state in the courts, the power of the executive in the governor, and the power of the legislature in the general assembly. See OHIO CoNST., art. IV, $\S 1$; art. III, $\S 5$; art. II, $\S 1$; see also Michael D. Blanchard, The New Judicial Federalism: Deference Masquerading as Discourse and the Tyranny of the Locality in State Judicial Review of Education Finance, 60 U. PITT. L. REV. 231, 249-52 (1998) (discussing the separation of powers and political question doctrine rationales as they arise in education finance cases).

60 Ohio Legislative Service Commission, "Budget in Brief," at http://www.lbo.state.oh.us/124ga/budget/BudgetInBrief/bib124.htm (last visited Sept. 14, 2002).

${ }^{61}$ See, e.g., DeRolph III, 754 N.E.2d 1184, 1209-10 (Ohio 2001) (Douglas, J., concurring) (explaining that if the Court were to declare the state's education budget unconstitutional, $\$ 1,400,000,000$ would be returned to the state budget for reallocation).

62 The history of Brown v. Board of Education and its progeny demonstrates that persistent resistance, delay, and frequent return trips to court can avoid the social change that the enforcement of the legal right would require. See generally GARY ORFIELD \& Susan E. Eaton, Dismantling Desegregation, the Quiet Reversal of Brown v. BOARD OF EDUCATION (1996); see also STEPHEN C. HALPERN, ON THE LIMITS OF THE LAW 304-21 (1995) (discussing the difficulty of enforcing desegregation in the context of political and popular resistance).

${ }^{63}$ See, e.g., Baker v. Carr, 369 U.S. 186, 267 (1962) (Frankfurter, J., dissenting) ("Disregard of inherent limits in the effective exercise of the Court's 'judicial Power' may well impair the Court's position as the ultimate organ of 'the supreme Law of the Land'...."). 


\section{COURT-ORDERED MEDIATION IN SCHOOL FUNDING}

respect of the legislature and the executive not only for its stature and authority, but also for its budget.

The remedial problem is particularly thorny. The court is not capable on its own of devising and imposing a remedy that would be sufficiently democratic to satisfy institutional legitimacy concerns in a representative democracy. On the other hand, if the court returns the task of devising a remedy to the legislature, it returns the problem to a democratic process that has already failed to meet constitutional educational requirements-a process that, given the power of the vested interests opposing reform, is likely to continue to fail. ${ }^{64}$

\section{B. The Potential for Mediation}

Although the remedial process in public law litigation may take many forms, ${ }^{65}$ mediation - or, a process for "developing a consensual remedy through joint fact-finding and collaborative decision-making assisted by a [neutral] third party"66 - holds special promise for achieving satisfactory results in school finance reform litigation. In important ways, the strengths of mediation speak directly to the difficulties of designing and implementing a remedy in complex, contested public law litigation. Mediation provides a flexible, participatory process that could serve to improve both the quality and legitimacy of the remedy in school finance reform cases.

Mediation, broadly defined, is a structured conciliation process that uses a neutral party to facilitate discussion, negotiation, and, if possible, resolution of a dispute. ${ }^{67}$ The mediator has no power to impose a resolution, but instead

64 In this regard, school finance reform litigation is analogous to prison reform litigation, about which Professor Sturm wrote, "[c] ourts correctly perceive, either initially or after years of noncompliance, that the underlying causes of the legal violation disable the defendants from complying with a general directive to cease violating the law." Sturm, supra note 8 , at $1362-63$.

${ }^{65}$ Professor Sturm identifies the various models for remedial process to include traditional adjudication, the bargaining model, the legislative or administrative hearing model, the expert remedial formulation model and the "consensual remedial formulation model," which I call "mediation." See id. at 1365-77.

${ }^{66}$ Id. at 1373-74. Professor Sturm uses the term "consensual remedial formulation model" to describe the kind of flexible process that I envision when I use the term "mediation" in this article.

${ }^{67}$ Mediation has also been defined as a procedure for resolving controversies based on complete agreement, using a third party neutral who has no preference for settlement terms, and has no authority to impose a solution. See JAMES J. ALFINI ET AL., MEDIATION THEORY AND PRACTICE 1 (2001). 
works with the parties to find a mutually agreeable solution to the problems at hand by providing a forum for exchange of information and for the generation of creative solutions that meet the fundamental interests of all of the parties. ${ }^{68}$

Providing an opportunity for collaborative problem-solving and creative thinking about alternative solutions may be particularly valuable in school finance reform, where the content of the remedy is not dictated by the finding of a legal violation. ${ }^{69}$ The first-and perhaps most important-potential benefit of using a consensus-building process to design the remedy is the improved quality of the remedy. ${ }^{70} \mathrm{~A}$ mediation process may employ the services of various experts and may bring the expertise of the various participating parties to bear on the remedial problems. ${ }^{71}$ Participation in a face-to-face negotiation process leads to better information production, enables parties to educate each other, to pool knowledge, to build on the expertise of various participants, and, ultimately, to arrive at high-quality results. $^{72}$

The exchange of information and values that takes place in a consensusbuilding process may not only improve the quality of the proposed solution, but may also increase its legitimacy. Mediation gives the parties control over the form of the remedy in a dispute and often results in solutions that are more satisfactory to the parties than any resolution that could have been imposed by court order. Further, mediation may be structured in a way that is accessible to the various constituencies who will ultimately be affected by the resolution of the dispute. In this way, "mediation is a process that takes seriously the philosophy of democratic decision-making." 73 It may be

68 Stephen B. Goldberg, Frank E.A. Sander \& Nancy Rogers, Dispute Resolution: Negotiation, MEdiation and Other Processes 103 (3d ed. 1999).

${ }^{69}$ See text and accompanying notes supra, at 53-58; see also Sturm, supra note 8, at 1377.

${ }^{70}$ See Jody Freeman \& Laura I. Langbein, Regulatory Negotiation and the Legitimacy Benefit, 31 E.L.R. 10811 (2001) (evaluating empirical data relating to environmental regulatory negotiations and concluding that the consensus-building process improved rule quality).

71 Id see also Susan L. Carpenter \& W. J. D. Kennedy, Managing Public DISPUTES 167-68 (2001) (discussing the role of technical resource experts).

72 CARPENTER \& KENNEDY, supra note 71 , at 124-26 (discussing the value of parties' educating each other about the problem and the data). In the DeRolph case, as discussed below, the failure of the parties to share important information with each other and with the Court led to the entry of an order based on incorrect budget numbers. See infra notes 130-33.

${ }^{73}$ ALFINI, supra note 67, at 1. 


\section{COURT-ORDERED MEDIATION IN SCHOOL FUNDING}

structured to consider the views of all of the affected parties. In school finance reform litigation, where a diverse group of organizations, systems and individuals will be affected by the selected remedy, mediation may supply the important benefit of providing a forum for these constituencies to voice their concerns, interests and values.

Moreover, when the parties and the various non-party stakeholders in the litigation have played an important role in formulating the remedy, compliance with the mediated outcome is generally as high or higher than compliance with adjudicated outcome. ${ }^{74}$ The implementation of a remedy devised through a participatory, consensus-building process may also be easier to achieve "because obstacles to implementation would likely surface and be addressed during negotiations." 75 Additionally, the mediation process may work to improve communication among parties, increase understanding, and, perhaps even create a transformative dialogue that permanently alters the dynamics of the relationships among the parties. ${ }^{76}$ The best possible outcome for mediation is not only to resolve the conflict at hand, but also to lay the groundwork for improved future interaction. In the realm of school finance, the need for the interested parties to continue to interact is patent: Budgets must be hammered out every year; student populations ebb and flow; standards of achievement change. In this context, the most attractive feature of mediation may be its potential for creating a transformative dialogue and improving future discussion of school finance issues.

\section{The DERolPH CASE: A BRIEF History}

The history of the DeRolph case provides a lens for viewing the problems of school finance litigation that are described in the abstract above

${ }^{74}$ Craig A. McEwen \& Richard J. Maiman, Mediation in Small Claims Court: Achieving Compliance Through Consent, 18 L. \& SOC'Y. REV. 11, 23 (1984) (describing empirical research showing high levels of satisfaction and compliance with mediated settlements). But see Roselle L. Whissler, Court-Connected Mediation in General Civil Cases: What We Know from Empirical Research, 17 OHIO. ST. J. ON DISP. RESOL. 641, 695 (2002) (stating that empirical studies comparing mediated settlements to nonmediated settlements do not demonstrate that mediation produced increased compliance or reduced post-settlement disputing).

75 See generally Freeman \& Langbein, supra note 70, at 10814 ("Surely the parties would be more likely to implement a rule they helped to develop, and less inclined to sue."); see also id. n.34 \& 38.

76 Robert A. Baruch Bush, The Unexplored Possibilities of Community Mediation: A Comment on Merry and Milner, 21 LAW \& SoC. INQUIRY 715, 733-36 (1996) (discussing the transformative mediation theory). 
and the potential for mediation to provide an improved resolution. In 1991, five Ohio school districts filed suit on behalf of Nathan DeRolph and other students, ${ }^{77}$ alleging that the public school funding system was unconstitutional under the section of Ohio's constitution that requires the General Assembly to provide enough funding to secure a "thorough and efficient system of common schools throughout the State." 78 During a trial that lasted 30 days, plaintiffs presented an overwhelming body of evidence demonstrating the inequality, inefficiency, and inadequacy of schools under the existing funding system. ${ }^{79}$ The evidence was largely uncontested by the defendant, the State Board of Education, which "not only advocated comprehensive reform but... stated the following three goals of such reform: equity, adequacy, and reliability of school funding." 80 The trial court determined that several provisions of the Ohio's school funding scheme violated the Ohio Constitution and ordered the "Superintendent of Public Instruction and the State Board of Education to prepare legislative proposals for submission to the General Assembly to eliminate wealth-based disparities among Ohio's public school districts." 81 Although the State Board of

77 DeRolph I, 677 N.E.2d 733, 735 (Ohio 1997). The predecessor of this suit was an action brought by the Cincinnati City Board of Education in 1976 challenging the school finance system under the Ohio state constitution. See Bd. of Educ. v. Walter, 390 N.E.2d 813 (Ohio 1979). In that case, the Ohio Supreme Court found no violation of the state constitution based on the specific facts presented relating to the then-existing funding scheme. Id. at 825. In 1989, the Coalition of Rural and Appalachian Schools conducted a study of Ohio school finance which concluded that Ohio's system was inadequate and inequitable. Public discussions of this study led to the organization of the Ohio Coalition for Equity and Adequacy of School Funding in 1991. William L. Phillis, The Ohio Experience: The School Funding Litigation Saga Continues On and On, at http://www.ohiocoalition.org/PDFs/TheOhioExperience.pdf (last visited Sept. 2, 2002). The Ohio Coalition for Equity and Adequacy filed the DeRolph lawsuit, naming Youngstown City School District Board of Education, Mahoning County; the Lima City School District Board of Education, Allen County; the Dawson-Bryant Local School District Board of Education, Lawrence County; the Northern Local School District Board of Education, Perry County; the Southern Local School District Board of Education, Perry County; superintendents, members of the boards of education of these districts and various teachers, students and next friends as plaintiffs. Id.; DeRolph I, 677 N.E.2d at 734.

${ }^{78}$ DeRolph I, 677 N.E.2d at 734.

${ }^{79}$ Id. The trial created more than five thousand six hundred pages of transcript and four hundred and fifty exhibits. Witnesses for both the plaintiffs and defendants testified to the inadequacies of Ohio's system of school funding and the need for reform. Id.

${ }^{80} \mathrm{Id}$.

81 Id. at 735 . 
Education voted not to appeal, the Attorney General filed notice of appeal. ${ }^{82}$ The trial court was reversed by the Court of Appeals, ${ }^{83}$ and the case came to the Ohio Supreme Court on discretionary appeal. ${ }^{84}$

In March 1997, the Ohio Supreme Court ruled in a four to three decision that the State had not fulfilled its constitutionally mandated duty to provide for a "thorough and efficient system of education." ${ }^{85}$ The majority opinion recited evidence showing that many children in Ohio attended schools in decaying and unsafe buildings and lacked basic materials for learning. ${ }^{86}$ Textbooks, paper, chalk, art supplies and even toilet paper were lacking or were rationed in some districts. ${ }^{87}$ Schools in poor districts lacked library facilities, food services facilities and access to computers and other technologies.88 High percentages of students in poor districts failed proficiency tests and were not eligible to graduate from high school. ${ }^{89}$

The court reviewed the system of funding that created great disparities between wealthy and poor districts, noting several problems that left some districts without sufficient funds. The court cited the State's reliance on a residual budget funding approach, its reliance on local property taxes, the requirement of school district borrowing, and lack of sufficient state funds for construction and maintenance of buildings as particularly problematic. ${ }^{90}$ The majority concluded that the State's statutory scheme was incapable of achieving its constitutional purpose. ${ }^{91}$ The court held 16 separate provisions of the state code to be unconstitutional. ${ }^{92}$ The school-financing scheme was

82 Id.

83 See DeRolph v. State, 1995 WL 557316 (Ohio Ct. App. Aug. 30, 1995). The Court of Appeals concluded, in part, that any changes needed in the method of funding public schools are properly a matter for the discretion of the legislative branch of the government rather than the judicial branch. Id. at *5.

${ }^{84}$ DeRolph I, 677 N.E.2d at 735.

85 Id. at 736. Section 2, article VI of the Ohio Constitution provides: "The general assembly shall make such provisions, by taxation, or otherwise, as, with the income arising from the school trust fund, will secure a thorough and efficient system of common schools throughout the state." OHIO CONST. art. VI, § 2.

${ }^{86}$ DeRolph I, 677 N.E.2d at 743-46.

${ }^{87}$ Id. at 744.

${ }^{88}$ Id. at $743-46$.

$89 \mathrm{Id}$. at $744-45$.

$90 \mathrm{Id}$. at 747 .

91 Id.

92 Id. (holding the following specific provisions to be unconstitutional: R.C. 133.301 (giving school districts authority to borrow money); R.C. $3313.483,3313.487,3313.488$, 3313.489, and 3313.4810 (providing for emergency school assistance loans); R.C. 
unconstitutional and required a complete overhaul. ${ }^{93}$

The court stayed the effect of the decision for a year to allow time for new legislation to be enacted and remanded the case to the trial court with directions to retain jurisdiction "until the legislation is enacted and in effect, taking such action as may be necessary to ensure conformity with this opinion." 94 The majority did not give the legislature specific directions on how to correct the deficiencies of the funding scheme. ${ }^{95} \mathrm{It}$ did, however, "admonish the General Assembly that it must create an entirely new school financing system"96 and set forth several clear benchmarks for a constitutionally adequate funding system.

First, the court made clear that the duty to fund schools falls on the General Assembly, not on the local districts. Funding schools must be a high budgetary priority; according to the court. ${ }^{97}$ "A thorough and efficient system of common schools," the majority concluded, "includes facilities in good repair and the supplies, materials, and funds necessary to maintain these facilities in a safe manner, in compliance with all local, state, and federal mandates." 98 The court identified four additional aspects of the schoolfunding scheme that needed to be eliminated, specifically:

(1) the operation of the School Foundation Program, (2) the emphasis of Ohio's school funding system on local property tax, (3) the requirement of school district borrowing through the spending reserve and emergency school assistance loan programs, and (4) the lack of sufficient funding in the General Assembly's biennium budget for the construction and maintenance of public school buildings. ${ }^{99}$

A three-member minority of the court—comprised of Justices Moyer,

$3317.01,3317.02,3317.022,3317.023,3317.024,3317.04,3317.05,3317.051$, and 3317.052 (The School Foundation Program); R.C. Chapter 3318 (The Classroom Facilities Act)). The Classroom Facilities Act was held to be unconstitutional only to the extent that it was underfunded.

${ }_{93}$ Id.

94 Id.

95 Id. ("Although we have found the school financing system to be unconstitutional, we do not instruct the General Assembly as to the specifics of the legislation it should enact.").

96 Id.

${ }^{97} I d$. ("Because of its importance, education should be placed high in the state's budgetary priorities.").

98 Id.

${ }^{99}$ Id. 


\section{COURT-ORDERED MEDIATION IN SCHOOL FUNDING}

Cook, and Lundberg Stratton-dissented, finding no constitutional violation and arguing that the majority had exceeded its authority. 100 "The issues of the level and method of funding, and thereby the quality of the system," wrote Chief Justice Moyer, "are committed by the Constitution to the collective will of the people through the legislative branch." 101 Chief Justice Moyer raised the specter of the long-lived school finance controversies in New Jersey, Texas, California, and Connecticut. ${ }^{102}$ School finance litigation in these states, he argued, demonstrates the "grim reality of a state supreme court involving itself in setting minimum educational standards, which has resulted in years of protracted litigation, ultimately placing the courts in the position of determining state taxation methods, budgetary policies, and educational policy." 103 Although the dissenters did not endorse the status quo in schools, they argued that the majority's decision violated the separation of

${ }^{100} \mathrm{Id}$. at 782-95 (Moyer, C.J., dissenting).

$101 \mathrm{Id}$. at 782 .

102 Chief Justice Moyer included an extended list of citations to school finance cases in these states to demonstrate the "troubled history of litigation that ensues when the judiciary deems itself to be the ultimate authority in setting educational funding mechanisms and standards." Id. at 786. Chief Justice Moyer included the following cases as examples of the problem:

New Jersey: Robinson v. Cahill (1973), 62 N.J. 473, 303 A.2d 273 (“Robinson I"), followed by Robinson v. Cahill (1973), 63 N.J. 196, 306 A.2d 65 ("Robinson II"); Robinson v. Cahill (1975), 67 N.J. 35, 335 A.2d 6 ("Robinson III"); Robinson v. Cahill (1975), 67 N.J. 333, 339 A.2d 193 ("Robinson IV"); Robinson v. Cahill (1976), 69 N.J. 449, 355 A.2d 129 ("Robinson V"); Robinson v. Cahill (1976), 70 N.J. 155, 358 A.2d 457 ("Robinson VI"); Robinson v. Cahill (1976), 70 N.J. 464, 360 A.2d 400 ("Robinson VII"); Abbott v. Burke (1985), 100 N.J. 269, 495 A.2d 376 ("Abbott I"), followed by Abbott v. Burke (1990), 119 N.J. 287, 575 A.2d 359 (“Abbott II"); Abbott v. Burke (1994), 136 N.J. 444, 643 A.2d 575 (“Abbott III"); Texas: Edgewood Indep. School Dist. v. Kirby (Tex.1989), 777 S.W.2d 391 ("Edgewood I"), followed by Edgewood Indep. School Dist. v. Kirby (Tex.1991), 804 S.W.2d 491 ("Edgewood II"); Carrollton-Farmers Branch Indep. School Dist. v. Edgewood Indep. School Dist. (Tex.1992), 826 S.W.2d 489 ("Edgewood III"); California: Serrano v. Priest (1971), 5 Cal.3d 584, 96 Cal.Rptr. 601, 487 P.2d 1241 ("Serrano I"), followed by Serrano v. Priest (1977), 18 Cal.3d 728, 135 Cal.Rptr. 345, 557 P.2d 929 ("Serrano Il"); Serrano v. Priest (Cal.App.1986), 226 Cal.Rptr. 584 ("Serrano III"); Butt v. State (1992), 4 Cal.4th 668, 15 Cal.Rptr.2d 480, 842 P.2d 1240; Connecticut: Horton v. Meskill (1977), 172 Conn. 615, 376 A.2d 359 ("Horton I"), followed by Horton v. Meskill (1982), 187 Conn. 187, 445 A.2d 579 ("Horton II"); Horton v. Meskill (1985), 195 Conn. 24, 486 A.2d 1099 ("Horton III”); Sheff v. O’Neill, (1996), 238 Conn. 1, 678 A.2d 1267.

Id. at 786 .

103 Id. at 787 . 
powers doctrine and decided a nonjusticiable question. ${ }^{104}$

Following the 1997 Ohio Supreme Court decision, Governor George Voinovich proposed a one-cent sales tax to raise money for schools. ${ }^{105}$ This measure died in the House; a similar measure was eventually submitted to the voters and was defeated in May 1998.106 Meanwhile, the General Assembly enacted several school reform provisions, including statutes creating the Ohio School Facilities Commission, establishing school district performance standards, and making appropriations for emergency repairs. ${ }^{107}$ In November 1998, out-going Governor Voinovich hired Achieve, Inc.-a group founded in 1996 by governors and business leaders and staffed by conservative scholars-to provide the General Assembly, incoming Governor Robert Taft, the new State Superintendent of Education, and state legislators with "a candid assessment of the strengths and weaknesses of Ohio's reform strategy." 108 The work of that group was on-going when the time to report back to the trial judge, Judge Lewis, arrived.

In the summer of 1998, the plaintiffs returned to the trial court maintaining that the General Assembly had failed to comply with the mandate of the Supreme Court. ${ }^{109}$ The trial court agreed, and a second appeal to the Ohio Supreme Court ensued. 110 While awaiting hearing before the Supreme Court, school-funding issues gained prominence in the General Assembly. In June 1999 the recently elected Governor Taft signed into law the state's first separate education budget. 111 In September 1999, Governor Taft announced a 12-year plan to replace and renovate aging school buildings. ${ }^{112}$ In March of 2000, the General Assembly allocated 2.5 billion dollars from the state tobacco case settlement to pay for school construction

104 Id. at 795.

105 School Funding Timeline, DAYTON DAILY NEws, Sept. 7, 2001, at 10A.

106 DeRolph v. State, 712 N.E.2d 125, 145 (Ohio Com. Pl. 1999).

107 S.B 102, 122nd Gen. Assem., Reg. Sess. (Oh. 1997); S.B. 55, 122nd Gen. Assem., Reg. Sess. (Oh. 1997); H.B. 650, 122nd Gen. Assem., Reg. Sess. (Oh. 1997); see also DeRolph, 712 N.E.2d at 144-59 (describing each new program and its implementation through August 1998).

108 DeRolph II, 728 N.E.2d 993, 1001 n.1 (Ohio 2000). Former Governor Voinovich was a member of Achieve Inc.'s Board of Directors at the time the time the case came before the Ohio Supreme Court. Id.

${ }^{109}$ DeRolph, 712 N.E.2d at 125.

110 DeRolph II, 728 N.E.2d at 993.

111 School Funding Timeline, DAYTON DaILY NEws, Sept. 7, 2001, at 10A.

112 Id. 
and repair. ${ }^{113}$ Meanwhile, Achieve, Inc., the group appointed by the Governor to study Ohio's schools, reported:

Ohio can be proud of a substantial set of policy initiatives it has launched in the 1990s, and of the deepening investments it has made in educational improvement. Since Fiscal Year 1991, state education funding has increased by approximately 50 percent, twice the rate of inflation. The increase has been greatest for low-wealth districts. Legislation already enacted guarantees an additional 40 percent increase in state aid over the next five years. 114

On May 11, 2000, in a second divided opinion-split along the same lines as the DeRolph I decision-the Supreme Court reviewed the efforts of the General Assembly and declared them to be insufficient to correct the constitutional deficiencies of the school funding system. ${ }^{115}$ The steps taken by the General Assembly fell short of correcting the constitutional problems, the majority opined, because it had not addressed the system's over-reliance on local property taxes. ${ }^{116}$ Further, the General Assembly had not adjusted the basic aid formula to reflect the amount actually needed to educate each child; had not appropriated sufficient funds to repair and replace decrepit school buildings; had enacted new unfunded mandates placing new requirements on school districts; and had not corrected problems relating to the calculation of revenue available from local property taxes. ${ }^{117}$

The majority acknowledged the difficulty and complexity of revising the funding scheme and carefully avoided telling the legislature what specific new laws must be enacted. ${ }^{118}$ It did, however, attempt to give substance to the "thorough and efficient" standard, saying,

A thorough system means that each and every school district has enough funds to operate. An efficient system is one in which each and every

113 S.B. 192, 123d Gen. Assem., Reg. Sess. (Ohio 2000); OHIo REv. Code ANN. $\S \S 183.02(\mathrm{~F}), 183.26$ (Anderson 2002).

114 DeRolph II, 728 N.E.2d at 1001.

$115 \mathrm{Id}$. at 1020 . ("We acknowledge the effort that has been made, and that a good faith attempt to comply with the constitutional requirements has been mounted, but even more is required.").

$116 \mathrm{Id}$. at 1021 . (Failure to address the problem of reliance on local property taxes "will make it exceedingly difficult for any system of school funding to comply with the Thorough and Efficient Clause, since the inherent inequities will remain.").

117 Id.

118 Id. at $1019-20$. 
school district in the state has an ample number of teachers, sound buildings that are in compliance with state fire and building codes, and equipment sufficient for all students to be afforded an educational opportunity. 119

The court retained jurisdiction over the case, continuing it until June 2001 when the parties would return before the Supreme Court and a new briefing schedule would be put in place. ${ }^{120}$ The court declined to appoint a special master to oversee the State's compliance with the court's order. ${ }^{121}$ Instead of relying on any court-allied process, the majority returned the dispute to the political fray, saying,

We hope that partisan views will be put aside and that everyone will work cooperatively for Ohio's children, as they are our future. The General Assembly, in particular, must look beyond the political considerations involved, and must provide Ohio's school children with a thorough and efficient system of common schools, as the Ohio Constitution requires. ${ }^{122}$

The court quoted the hopeful rhetoric of the Achieve, Inc. report: "This may be a propitious moment to forge a new social compact between Ohio's government policymakers and its education community." 123 As later events would reveal, the moment was not as propitious as it then appeared to be.

Following the May 2000 ruling, action on the Supreme Court's mandate appeared to stall in the General Assembly. The joint legislative committee that was formed to recommend funding changes met only a few times. ${ }^{124}$ Meanwhile the Ohio Chamber of Commerce backed a multi-million dollar campaign to defeat Justice Alice Robie Resnick, the author of the DeRolph II majority decision, in her campaign for reelection. ${ }^{125}$ State budget cuts were predicted. Following the landslide reelection of Justice Resnick, however, the Ohio General Assembly once again embarked on a legislative tour through the school funding provisions, making a series of revisions and new appropriations. With only one month left before the scheduled argument

119 Id. at 1001 .

$120 \mathrm{Id}$. at 1022.

121 The Court's decision not to appoint a special master appears without comment or analysis. $I d$.

122 Id. at 1021 .

123 Id. at 1022.

124 Catherine Candisky \& Lee Leonard, School Funding Plan Won't Fit State Budget, COlUmBus DiSPaTCH, Nov. 12, 2000, at A1.

125 Emily Heller \& Mark Ballard, Hard-Fought, Big-Money Judicial Races: U.S. Chamber of Commerce Enters Fray with Ad Money, NAT. L. J., Nov. 6, 2000, at A1. 
before the Supreme Court, the General Assembly passed a biennium budget that included changes in the school funding formula. ${ }^{126}$ By now, however, the economy had begun to sour. "State sales tax revenue in the July through October period fell $\$ 80$ million short of estimates." 27 Rather than raise additional tax revenue to cover the additional school expenditures, however, Governor Taft and the legislature cut budgets of other government offices and agencies. ${ }^{128}$

When the case reappeared on the Supreme Court docket in the summer of 2001, however, plaintiffs were adamant that the State had failed to follow the mandate of DeRolph I and DeRolph II. The State had not corrected the over-reliance on local property taxes, had put in place what plaintiffs alleged to be a faulty formula for calculating state aid, and had failed to address various factors that put revenue pressure on local school districts. ${ }^{129}$

Defendants maintained that its legislative effort to improve schools was producing greatly increased revenue for schools and improving quality and standards of performance. State per pupil allocations had been increased; a 12 -year, $\$ 23$ billion plan to repair and replace old schools was in place; special allocations called "parity aid" would now give additional funds to poorer districts; and new proficiency tests had been devised. ${ }^{130}$

The Ohio Supreme Court found itself in a difficult position as it set out to make its third decision on the constitutionality of the school funding scheme. ${ }^{131}$ Four years after its bold decision declaring the funding system to be unconstitutional, state budget allocations for schools had increased, but the "complete overhaul" that was directed in the 1997 decision had not taken place. Political and media pressure on the court had become intense. The

126 School Funding Timeline, DAYTON DaILY News, Sept. 7, 2001, at 10A.

127 Back to School, Crain's Cleveland Bus., Nov. 27, 2000, at 10.

128 DeRolph III, 754 N.E.2d 1184, 1242 (Ohio 2001) (Sweeney, J., dissenting).

129 See William Hershey, School Funding Flaws Fixed, DAYTON DalLY News, June 19,2001 , at $1 \mathrm{~A}$.

Forces putting revenue pressure on local districts included business tax abatements, inventory tax phase-out (Am. Sub. H.B. 283, $123 \mathrm{~d}$ Gen. Assem., Reg. Sess. (Ohio 2000)), and the tax reduction factors that prohibit districts from realizing increased revenue as a result of appreciation of local property values. Am. Sub H.B. 920, 11th Gen. Assem., Reg. Sess. (Ohio 1976).

${ }^{130}$ DeRolph III, 754 N.E.2d at 1191-98.

131 The case had produced "three signed majority opinions, a per curiam opinion, eleven separate concurrences and dissents, and a number of rulings on motions filed by plaintiffs and defendants. "Id. at 1188. 
court was widely blamed for budget cuts in popular state programs. ${ }^{132}$ The General Assembly seemed incapable of making the structural changes in the system envisioned in DeRolph $I$ and $I I$, and the task of overseeing incremental revisions - tinkering toward a constitutional funding systemappeared endless. Further, if the court held the current scheme to be unconstitutional, it seemed likely that $\$ 1.4$ billion in additional budget allocations for education-already calculated in local school budgets-would "be reallocated to the other state institutions and programs so severely cut to accommodate the school funding plan."133 Three of the justices had consistently opposed the Supreme Court's involvement in school funding issues. Now, for two members of the original majority-Justice Douglas and Justice Pfeifer-finding some way to end the Supreme Court's involvement in school funding seemed to be central. ${ }^{134}$

The DeRolph $I I I^{135}$ decision issued on September 6, 2001, was a selfproclaimed compromise. ${ }^{136}$ Chief Justice Moyer, who had dissented from the majority opinions in both DeRolph I and DeRolph II, wrote for a threemember plurality that included justices Douglas and Pfeifer, members of the previous majorities. Justice Lundberg Stratton, formerly a member of the dissenting minority, filed a short opinion, concurring in the judgment only. Thus, the DeRolph III majority consisted of two members of the previous majority and two members of the previous minority. Chief Justice Moyer began by describing the differences of opinion existing among the justices on the court. Invoking the wisdom of Thomas Jefferson, however, he opined that the time had come to sacrifice individually held opinions for the sake of harmony. 137 "None of us," he admitted, "is completely comfortable with the decision we announce in this opinion." 138 He wrote,

A climate of legal, financial, and political uncertainty concerning Ohio's school-funding system has prevailed at least since this court accepted

132 Programs cut to accommodate the school funding plan included, inter alia, higher education, mental health, protection of battered women, and prison security. Id. at 1210 (Douglas, J., concurring).

$133 \mathrm{Id}$.

${ }^{134} \mathrm{Id}$. at 1214 (" $[\mathrm{I}] \mathrm{t}$ is the primary mission of this court to accept cases that properly invoke its jurisdiction under the Constitution, read briefs and hear arguments on those cases, decide the cases and then publish opinions... [and] any other combination of votes short of a majority of four would not be meeting our constitutional obligations.").

135 Id. at 1184 .

$136 \mathrm{Id}$. at 1190 .

137 Id.

${ }^{138} \mathrm{Id}$. at 1189. 
jurisdiction of the case. We have concluded that no one is served by continued uncertainty and fractious debate. In that spirit, we have created the consensus that should terminate the role of the court in this dispute. 139

Chief Justice Moyer went on to undertake a detailed review of the revised state law provisions for funding public schooling, noting changes relating to the calculation of the base per student allocation, ${ }^{140}$ the addition of "parity aid" for poorer districts, ${ }^{141}$ new programs to improve school facilities, ${ }^{142}$ new academic standards, ${ }^{143}$ and measures reducing the disparity in funding produced by funding schools through local property taxes. ${ }^{144}$ These measures, taken together, said Moyer, demonstrated a commitment by the legislature and the governor to improve public education in Ohio. ${ }^{145}$ The school-funding scheme, as it was presented to the court, required only two changes to meet constitutional scrutiny. With a change in the method of calculating the basic cost of an adequate education and full funding for the parity aid program, the state's school-funding program could be constitutionally implemented, Moyer concluded. ${ }^{146}$ These changes would require additional funding, but would not require a new legislative scheme. ${ }^{147}$

Chief Justice Moyer's opinion pulled together a fragile agreement among four justices, grounded more in policy and practical reasoning than in legal principle. Justice Lundberg Stratton, who provided the fourth vote for the majority, stated in her short concurrence that her opinion on the merits had not changed, but that she joined the majority as "a pragmatic compromise to resolve an impasse that I believe has been divisive for too long and for which the alternatives proposed by the dissents are truly unacceptable."148

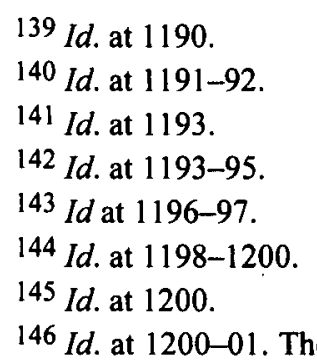

an adequate to calculate the per student cost of an adequate education had eliminated the top-spending districts from the equation. Chief Justice Moyer held that the "wealth screen" method of calculation resulted in a distorted picture of the amount actually needed to educate each child. Eliminating the wealth screen would require new calculations and new fiscal appropriations, but would not fundamentally alter the funding scheme. Id. at 1200 .

147 Id. at 1201.

${ }^{148}$ Id. at 1216 (Stratton, J., concurring). 
The opinions of the justices in the plurality reflect a strong desire to reach a resolution in a particularly difficult and divisive case. The justices considered a wide variety of remedial options, ${ }^{149}$ but did not discuss the possibility of appointing a mediator to assist the parties in resolving the dispute for themselves. Justice Douglas briefly entertained the option of appointing a special master or blue ribbon commission to oversee the remedial process, but rejected the idea without analysis, saying only "[t]here were never four votes for this approach."150

As conciliatory and tentative as is the tone of the plurality opinions, so are the dissents vehement. In strongly worded dissents, Justices Sweeney and Resnick, who were members of the majority in DeRolph I and II, detailed the continuing deficiencies of the state's funding scheme and criticized the majority for abandoning the principles enunciated in the previous two DeRolph decision. ${ }^{151}$ "The majority," wrote Justice Resnick, "places entirely too much importance on political expedience and not nearly enough on justice." 152 Justice Cook, taking a position on the ideological opposite end from justices Resnick and Sweeney, argued in her dissent that the decision of the majority illustrated the reasons why the court never should have become involved in school funding issues in the first place. ${ }^{153}$ The issues are necessarily questions of policy and should be left in the hands of the legislature. "The judicial oath of office," she declared, "requires me to support the Ohio Constitution and to perform the duties of a judge-not of a legislator."154

Almost before the Supreme Court photocopy machines were cool, the authority of the fragile four-member majority opinion came into question. Plaintiffs had based their arguments on incorrect numbers, howled state officials. ${ }^{155}$ If the state were to implement the changes in the method of calculating the per student base cost as required by DeRolph III, the increased cost to the state would far exceed the amount contemplated by the court. Instead of $\$ 400$ million, the changes required in DeRolph III would cost an additional $\$ 1.2$ billion. ${ }^{156}$

The court had been the subject of controversy before the DeRolph III

149 Id. at 1209-12 (Douglas, J. concurring).

$150 \mathrm{Id}$. at 1211 .

${ }^{151}$ Id. at 1223-35 (Resnick, J., dissenting); Id. at 1241-44 (Sweeney, J., dissenting).

152 Id. at 1241 . (Resnick, J., dissenting).

153 Id. at $1245-46$ (Cook, J., dissenting).

154 Id. at 1247.

155 Randy Ludlow, Taft Pleads Poverty, CinCINNATI Post, Sept. 22, 2001, at 16A. ${ }^{156} \mathrm{Id}$. 
decision; now the justices became the targets of public derision. One editorial in the Plain Dealer denounced the decision as follows:

The justices' unprincipled dash toward consensus on school funding resulted not in praise for their statesmanship or admiration for their ingenuity, but in deserved diatribes against their inconsistent, illogical reasoning. And, in what stands as perhaps the sweetest sort of justice, it now looks as though the court's majority didn't even understand what it did. 157

Indeed, the majority had based its assumptions on numbers that were incorrect. ${ }^{158}$ The changes required by DeRolph III would be much more expensive than the majority had anticipated and might throw the entire state budget process into disarray. The court granted the state's motion to reconsider and, in a move that was widely perceived to be a "punt,"159 referred the parties to mediation. ${ }^{160}$

\section{THE FAILURE OF THE DEROLPH MEDIATION}

A few short months after the DeRolph case was referred to mediation, the mediator reported back to the court that the parties were unable to reach a resolution. ${ }^{161}$ The newspapers proclaimed that the mediation was a "doomed" effort from its inception and its failure was a "foregone conclusion."162 The position of Justice Resnick, who had opposed referring the case to mediation, appeared to be vindicated. "Today the parties on each side are firmly entrenched in their positions," Justice Resnick had written. ${ }^{163}$ And "the oral arguments before us in this matter made it clear that mediation is an impractical solution." 164 Indeed, the uncompromising tone of the

${ }^{157}$ Chris Sheridan, Justices Drop Their Dignity and Run, Plain DeAler, Sept. 9, 2001 , at $\mathrm{H} 3$.

158 DeRolph Mediation, 758 N.E.2d at 1120 (Douglas, J., concurring). The majority had based its assumptions on inaccurate numbers that the state had provided to the plaintiffs.

159 Editorial, The Court Punts Again, Cincinnati Post, Nov. 21, 2001, at 16A.

160 DeRolph Mediation, 758 N.E.2d at 1114.

${ }^{161}$ Howard Bellman, Master Commissioner's Final Report, at http://www.sconet.state.oh.us/derolph/bellman3-21.pdf (last visited Oct. 21, 2002).

162 Editorial, The Last Word, COLumbus DisPaTCH, March 24, 2002, at D2.

163 DeRolph Mediation, 758 N.E.2d at 1122 (Resnick, J., dissenting).

${ }^{164}$ Id. at 1123 (quoting Claremont Sch. Dist. v. Governor, 725 A.2d 648, 651 (N.H. 1998)). 
arguments presented by the parties combined with the longevity and complexity of the dispute might seem to dim the realistic prospects of achieving a mediated resolution, making the mediation requirement nothing more than an expensive additional layer of process. ${ }^{165}$ But neither the strident tone of appellate oral arguments nor the number of years of inability to resolve their differences provides an accurate predictor of success in mediation. ${ }^{166}$

While there may be many reasons why the attempt to resolve the DeRolph litigation through mediation failed, ${ }^{167}$ I will focus on two matters that are highly determinative of success in any mediation, but that merit special attention in institutional reform litigation: (1) participant motivation, and (2) the identification and involvement of appropriate stakeholders. I will suggest that the best possibility for reaching a mediated resolution in a school

165 The costs of mediation in the DeRolph case can be measured concretely in terms of money and time. The monetary costs include $\$ 67,746$ billed by the mediator, and the attorneys' fees to pay for the parties' preparation and participation in the mediation process. See DeRolph v. State, 766 N.E.2d 994 (Ohio 2002); DeRolph v. State, 768 N.E.2d 658 (Ohio 2002). The time cost of the attempted mediation amounts to roughly six months delay in a decision by the Ohio Supreme Court on the merits of the motion to reconsider. Of course, the time "cost" may be interpreted as a true detriment to the plaintiffs, who await implementation of a remedy in the case, but as a benefit to the defendants, who seek to avoid a judicially imposed remedy. In cases where one party uses mediation to delay the settlement of the case, mediation can potentially add one more layer to a process that will eventually end up back in court. LAVINIA HALL, Negotiation: STRATEgIES For MUTUAL GaIN 57 (1993). These "costs" may seem fairly trivial in the scope of a case with an eleven-year history in litigation. Nevertheless, the law should not require a useless act. See, e.g., Ohio v. Roberts, 448 U.S. 56, 74 (1980) ("The law does not require the doing of a futile act."). If requiring mediation serves only to delay resolution, then court-ordered mediation cannot be justified.

166 Mori Irvine, Better Late Than Never: Settlement at the Federal Court of Appeals, 1 J. APP. PraC. \& Process 341, 342-46 (1999) (discussing reasons why "the most difficult, most intractable" cases may reach resolution when pending before the U.S. Court of Appeals).

167 The success of any mediation may be affected by highly particular factors such as the personalities and negotiating skills of the participants or the skill of the mediator. Because these factors do not lend themselves to generalization, they will not be discussed here at any length. I should mention, however, that the mediator who was appointed in this case, Howard S. Bellman, is a highly respected and eminently well-qualified mediator who has extensive experience in mediating environmental policy issues, labor contracts, and school disputes. It seems unlikely that the Court could have found any person who would have been better prepared than Mr. Bellman for the task of facilitating settlement in this case. For a list of the full qualifications of Mr. Bellman, see Howard S. Bellman, at Resume, http://www.sconet.state.oh.us/derolph/bellman_resume.pdf (last visited on September 13, 2002). 


\section{COURT-ORDERED MEDIATION IN SCHOOL FUNDING}

funding case-and perhaps in other institutional reform litigation - might be achieved in a process that resembles a public policy facilitation, but that remains closely tied to the court, with the accompanying prospect of court intervention for remediation and resolution. Such a process would require a clear and unequivocal statement by the court declaring the rights of the parties and remedial principles, incentives to permit participation by a broad range of non-litigant stakeholders, a generous time frame, and a team of highly skilled mediators.

\section{A. Motivation to Settle}

Mediation is a facilitated negotiation that depends for its success, to a large extent, on the motivation of the parties. None of the potential benefits of mediation may be realized unless the participants are motivated to resolve the dispute. ${ }^{168}$ Even when mediation is court-ordered, its goal is voluntary settlement. The court may compel attendance, but not resolution. ${ }^{169}$ Thus, mediation is driven by the professional, practical, and personal goals and motivations of the participants. ${ }^{170}$ Parties in a case that has been litigated II.B.

${ }^{168}$ For a discussion of the potential benefits of mediation, see supra Part

169 The authority of the Supreme Court of Ohio to order the parties to attend mediation is found in OHIO SUP. CT. R. 14(6), which provides as follows:

\section{Settlement Conferences}

(A) Referral of cases for settlement conferences

The Supreme Court may, sua sponte or on motion by a party, refer to a master commissioner for a settlement conference any case that originated in the court of appeals, any appeal from an administrative agency, any original action, or any nonfelony case that the Supreme Court deems appropriate. The master commissioner may conduct the settlement conference in person or by telephone. At the settlement conference, the parties shall explore settling the case, simplifying the issues, and expediting the procedure, and may consider any other matter that might aid in resolving the case.

(B) Attendance

If a case is referred for a settlement conference, each party to the case, or the representative of each party who has full settlement authority, and the attorney for each party shall attend the conference, unless excused, in writing, by the master commissioner to whom the case has been referred. If a party or an attorney fails to attend the conference without being excused, the Supreme Court may assess the party or the attorney reasonable expenses caused by the failure, including reasonable attorney fees or all or a part of the expenses of the other party. The Supreme Court may also dismiss the action, strike documents filed by the offending party, or impose any other appropriate penalty.

${ }^{170}$ Irvine, supra note 166 , at 346. 
through judgment and appeal, or, as in this case, through several judgments and several appeals, may have considerable resistance to settlement. ${ }^{171}$ Without significant motivational incentives for settlement, parties are unlikely to set aside strongly held positions. Experience in appellate mediation has demonstrated, however, that despite the hardening of positions that occurs in prolonged litigation, parties frequently have strong motivation to settle a case pending on appeal. ${ }^{172}$ In even the most long-lived and seemingly intractable disputes, the parties may be moved to settle by a variety of factors including, (1) a professional assessment of the risks of an unfavorable decision by the court; (2) the cost of continued litigation; (3) the need for immediate relief; (4) the possibility of achieving a flexible or creative result that might not be available by court-order; and (5) the desire to reach a fair resolution of the problem. ${ }^{173}$ The common thread in the first three factors just mentioned is some identifiable risk of continuing to litigate or an identifiable benefit of immediate settlement. Without some risk inherent in the legal process (or in the delay involved in using the process) and aversion to that risk, ${ }^{174}$ it may be difficult to generate motivation to settle.

\section{The Court's Role in Defining the Risk of Non-Settlement}

Generally, incentives to settle operate in institutional reform litigation as they would in any litigation. ${ }^{175}$ The court must, however, deliver the case to mediation with the incentives to settle intact. This is particularly true in a

171 Thomas F. Ball, III, Appellate Mediation in the Fourth Circuit: An Idea that Works, S.C. LAw., Nov.-Dec. 1997, at 29-30 (explaining that mediating appeals is made more difficult by strong, indignant feelings on one side and the "glow of victory" on the other).

172 Irvine, supra note 166 , at $345-46$.

173 Ball, supra note 171 , at $30-31$ (listing fourteen factors that prompt appellate settlements).

174 Howard Bellman points out that what is perceived as a "risk" to one person may not be a risk to another. He cites the example from the tale, "The Tar Baby." See JOEL Chandler Harris, Brer RabBit (1978). In "The Tar Baby" Brer Fox captures Brer Rabbit and prepares to cook him up in a stew. Brer Rabbit feigns relief that he will be eaten-rather than subjected to a worse punishment. He begs Brer Fox not to throw him into the briar patch. Brer Fox, wanting to cause Brer Rabbit the maximum pain, throws Brer Rabbit into the briar patch. Brer Rabbit dances away, saying "I was bred and born in the briar patch!"

175 See generally Schlanger, supra note 10 (discussing incentives for settlement in prison reform litigation). 


\section{COURT-ORDERED MEDIATION IN SCHOOL FUNDING}

mandatory, court-ordered mediation. When it is necessary to order parties to attempt to resolve the dispute through mediation, it can be assumed thatwithout the order to mediate - the barriers to effective negotiation and settlement are higher than the parties' pre-existing motivation to settle. In mandatory mediation, it is the power of the court and the identified legal framework for decision that creates an impetus for settlement and, to some extent, sustains the parties' motivation to negotiate. ${ }^{176}$ The court plays a major role not only in creating the forum and structuring the process, but also in defining the risk of non-settlement. 177

The risk of non-settlement is defined in large part by the prospect of continued court action. The credible threat that the court will, in fact, take action if a settlement is not reached plays an essential role in motivating the parties to move toward resolution. In an ordinary private civil action, this is generally taken for granted. The parties know as they begin a court-ordered mediation that if no settlement is reached, the court will decide the case for them. Judgment will be entered and executed. In a case where the court has found that one party has violated the rights or property of the other, the litigants may properly expect that the party whose rights or property were violated will be vindicated and the wrongdoer will have to pay. ${ }^{178}$ The parties may assume that the court will impose a remedy that is not of the wrongdoer's own choosing. In a school funding case, however, these assumptions do not necessarily apply.

After finding constitutional violations in cases challenging school funding, state courts have frequently deferred to the legislature or executive

176 Harry T. Edwards, Alternative Dispute Resolution: Panacea or Anathema?, 99 HARV. L. REV. 668, 682 (1986) (observing that the option to resort to court adjudication provides essential motivation for cooperation in the process: "It is only because handicapped children have a statutory right to education that parent-school mediation is successful. It is only because tenants have procedural rights that landlords will bargain at all.").

${ }^{177}$ Another way that negotiation theorists describe the dynamics surrounding the "risk of non-settlement" uses the term "BATNA" or "Best Alternative to a Negotiated Agreement." See generally Roger Fisher \& WiLliam URY, GetTING TO Yes: NEGOTIATING AGREEMENT WiTHOUT GIVING IN 101-11 (1981). If the BATNA compares negatively to the proposal offered in negotiation, there will be an incentive to accept the offered proposal. How parties conceive their BATNAs relates to their individual perception of risk and their risk aversion. See LAWRENCE SUSSKIND \& JEFFREY CRUIKSHANK, BREAKING THE IMPASSE 81-85 (1987).

178 This is, of course, a dramatic simplification of the complex calculus that may inform the thinking of litigants entering mediation. For an expanded list of factors affecting motivation to settle appeals, see Ball, supra note 171, at 30-31. 
to fashion a remedy. ${ }^{179}$ Rather than impose a remedy of its own making, a state court dealing with a school funding case is likely to put the task of designing a remedy back in the hands of the defendant, the rights-violating party. ${ }^{180}$ Even where the legislature has repeatedly failed to implement a remedy that satisfactorily addresses the identified constitutional violations, courts have left the task of formulating a remedy in the hands of the legislature. ${ }^{181}$ If the participants representing the legislature can anticipate that the legislature will be allowed to choose its own remedy following an unsuccessful mediation, they may perceive no risk inherent in failing. ${ }^{182}$ It hardly needs to be pointed out that, "[n]o group should choose to be part of a negotiation if what it can obtain 'away from the bargaining table' is better than what it is likely to get by negotiating." 183 The court's deference to the legislature on the issue of remedy has the effect of taking the wind out of the motivational sails of the mediation process. ${ }^{184}$

179 Yudof, supra note 39, at 587; Michael A. Rebell \& Robert L. Hughes, Efficacy and Engagement: The Remedies Problem Posed by Sheff v. O'Neill-and a Proposed Solution, 29 CONN. L. REV. 1115, 1134 (1997).

180 Professor Wendy Parker points out that the U.S. Supreme Court's decisions in a related area of litigation, school desegregation cases, have created a similar phenomenon. In school desegregation cases, she argues, the court's remedial "ambiguity allowed defendants to ... define the desired end result and, to a certain extent, the plaintiffs' rights themselves." Wendy Parker, The Supreme Court and Public Law Remedies: A Tale of Two Kansas Cities, 50 HASTINGS L. J. 475, 480 (1999).

181 Here, I mean only to describe an approach frequently taken by state courts. See, e.g., DeRolph II, 728 N.E.2d 993, 1021 (Ohio 2000) (holding that the General Assembly had not adequately addressed the constitutional violations identified in DeRolph I, 677 N.E.2d 733 (Ohio 1997), but deciding that "the best course of action is to provide the defendants more time to comply ..."); see also Abbott I, 495 A.2d 376, 394 (N.J. 1985), followed by Abbott II, 575 A.2d 359, 408 (N.J. 1990); Abbott III, 643 A.2d 575, 579 (N.J. 1994) (repeatedly returning school funding case to the legislature for remediation). I do not mean to suggest that repeated deferral to the legislature or executive is legally required or desirable.

182 A legislative participant in a failed school funding mediation might reasonably expect to be thrown like Brer Rabbit back into the briar patch, which, for the legislator, would be the General Assembly. See generally HARRIS, supra note 174.

183 SUSSKIND \& CRUIKSHANK, supra note 177 , at 81.

184 The continued involvement of the courts in the process of devising and implementing a remedy is crucial to the success of the mediation process. Experience has demonstrated time and again that repeatedly returning a school finance case to the legislature for the formulation of a remedy is unsatisfactory. See Rebell \& Hughes, supra note 179, at 1146. DeRolph itself stands as a prime example. Other examples of legislative inefficacy in fashioning a remedy include Abbott, Sheff, and others. See, e.g., cases cited by Chief Justice Moyer, supra, note 102. 
Courts defer the remedial process to the legislature in school finance cases for a number of theoretical and practical reasons related to the judiciary's own power, legitimacy, and competency. ${ }^{185}$ It is beyond the scope of this article to undertake a full discussion of the separation of powers and political question doctrines that underlie judicial deference to the legislature in school finance cases. ${ }^{186}$ Nevertheless, the prospects for successful mediation are dimmed unless the court expresses the determination to take hold of the remedial reigns if the mediation process fails. In other words, if the court wants the mediation process to be successful, it should send the parties to mediation with clear forewarning that it will not continue to defer to the legislature for resolution if the process fails.

Moreover, the court should refer the case to a mediation process early in the remedial phase of the litigation, before resentment has built up in the legislature and before the parties might infer from the court's actions an unwillingness or inability to act decisively if legislative action does not satisfy constitutional requirements. In the Ohio school finance litigation, the order referring the parties to mediation came when the litigation was more than a decade old, and after the Supreme Court had given the legislature an opportunity to cure constitutional deficiencies-not once, but twice. ${ }^{187} \mathrm{By}$

185 See supra text accompanying notes 38-63.

186 The goal of this paper is to explore whether and how mediation might be useful in resolving school funding cases. It does not attempt to analyze the separation of powers and political question doctrine, but instead assumes that the judiciary has the power to act in this arena. For argument supporting the exercise of judicial power in school finance cases, see Blanchard, supra note 59. Mr. Blanchard argues that state courts have strained to abdicate their authority over education finance under the aegis of the separation of powers and political question doctrines, which are federal doctrines that are not freely transferable to state constitutional analysis. Id. at $246-49$. He further argues that local control in school matters is a policy choice rather than a matter of state constitutional requirement and that the dangers of the tyranny of the majority are far more critical at the state level. Therefore, he asserts that state courts should exercise vigorous protection of individual rights under revitalized state constitutions. Id. See also, Robert A. Schapiro, Contingency and Universalism in State Separation of Powers Discourse, 4 ROGER WILLIAMS U. L. REV. 79 (1998) (arguing that federal separation of powers analysis is illsuited to state constitutional systems). Contrary argument may be found in David $\mathbf{J}$. Owsiany, The General Assembly v. the Supreme Court: Who Makes Public Policy in Ohio?, 32 U. TOL. L. REV. 549 (2001) (judicial action in school finance cases amounts to usurpation of legislative policy-making authority).

187 See generally DeRolph I, 677 N.E.2d 733 (Ohio 1997) (returning the matter to the legislature for action); DeRolph II, 728 N.E.2d 993 (Ohio 2000) (returning the matter to the legislature a second time); DeRolph Mediation, 758 N.E.2d 1113 (Ohio 2001) (referring the case to mediation). 
the time mediation was ordered, legislative resentment of the court's actions was palpable. Justice Douglas expressed his concern in DeRolph III:

[T]oday we live in different times. We hear from certain members of the General Assembly that we can say whatever we want but those pronouncements will be ignored. We hear some members of the General Assembly saying that impeachment of one or more justices might be in order and, in fact, we have one self-proclaimed constitutional law expert, a professor, advocating our impeachment or removal from office and stating that the General Assembly has a duty to ignore court orders . . . 188

An ideal mediation order in a school finance case would come early in the remedial phase of the litigation-perhaps after the court has given the legislature one opportunity to enact constitutional school funding legislation without further court action ${ }^{189}$-and would outline the procedures for resolution that the court will follow if the mediation effort is unsuccessful. The practice of setting forth the steps that will follow an unsuccessful mediation is already common in cases referred to mediation or to special masters in the federal court. ${ }^{190}$ Such an order would support the parties'

188 DeRolph III, 754 N.E.2d 1184, 1211 (Ohio 2001). The professor Justice Douglas refers to is undoubtedly Washington University School of Law Professor David $\mathbf{J}$. Owsiany, who published an article that criticizes the justices' decisions in school funding and tort reform cases. Professor Owsiany writes,

[T] he court engaged in brazen lawmaking and, in the process, usurped policymaking authority from the legislative and executive branches .... By acting to assert itself either by removing overreaching justices, ignoring the court's attempt to make policy, or introducing a constitutional amendment reaffirming the separation of powers, the legislature would be fulfilling its duty to resist judicial usurpation of legislative authority.

Owsiany, supra note 186 , at 561 .

189 The possibility that the legislature might take steps to cure constitutional deficiencies without further court action should not be discounted or ignored. In Vermont, the state legislature enacted a far-reaching school finance reform package just four months after the Vermont Supreme Court declared that the state's education finance system violated the state constitution. See Michael A. Rebell \& Jeffrey Metzler, Rapid Response, Radical Reform: The Story of School Finance Litigation in Vermont, 31 J.L. \& EDUC. 167, 167 (2002).

190 See, e.g., Vaughn G. v. Mayor of Baltimore, No. MJG-84-1911 (D.Md. Nov. 1, 1999) (setting forth detailed procedures for court determination of issues not resolved by the court-ordered mediation) (copy on file with the author). For an extended discussion of federal court practice in drawing the terms of orders appointing special masters, see James S. DeGraw, Rule 53, Inherent Powers, and Institutional Reform: The Lack of Limits on Special Masters, 66 N.Y.U. L. REV. 800 (1991). The language of the Ohio 


\section{COURT-ORDERED MEDIATION IN SCHOOL FUNDING}

motivation to participate by giving a clear picture of the remedial alternative that would be set in motion if the parties fail to reach a resolution of their own devising. For example, the court could decide in advance of the mediation that, in case of failure of the mediation, it would appoint an independent, five-member blue-ribbon commission. ${ }^{191}$ Specific details could be included. For example, the court could announce that the commission would be composed of members with expertise in law, finance, taxation, education and labor relations and would develop a specific legislative proposal to meet the state's constitutional requirements relating to school funding; and that the court would submit the commission's proposal to the legislature, following approval by the court, with an accompanying order to enact it. ${ }^{192}$ In its order setting up the mediation, the court could also demonstrate its commitment to an effective remedy by outlining sanctions that would be imposed if the legislature failed to enact the legislation formulated by the blue-ribbon commission. These sanctions might include escalating fines on the legislative body, or, perhaps, an order enjoining the collection of taxes pending favorable legislative action. ${ }^{193}$

Supreme Court Practice Rule that provides the authority for requiring settlement conferences and the appointment of a special master or mediator is similarly broad and contains no restrictions that would prevent the court from providing a procedural roadmap. See OHIO SUP. CT. PRAC. R. XIV(6).

191 Justice Douglas considered this option in DeRolph $I I I$, but stated that there were only three justices who supported the idea. DeRolph III, 754 N.E.2d at 1211.

$192 \mathrm{Id}$.

193 According to Professor Sturm, the authority of the court to exercise "coercive power to eliminate ongoing public law violations rests on a solid jurisprudential foundation." Sturm, supra note 8 , at 1378 . "The legitimacy of these techniques derives from the widely accepted principle that rights should find vindication in an effective remedy." Id. at 1379. The power of the court to coerce compliance with its orders through the use of its contempt power, including the use of fines, injunctions, or confinement, is inherent in the court and not subject to legislative control. See, e.g., City of Cincinnati v. Cincinnati Dist. Council, 299 N.E.2d 686 (Ohio 1973). Further, the inherent power of the courts, both state and federal, to effectuate a remedy that protects the constitutional rights of the parties generally includes the power to require a taxing authority to levy taxes. See, e.g., Missouri v. Jenkins, 495 U.S. 33, 57 (1990) ("[A] local government with taxing authority may be ordered to levy taxes in excess of the limit set by state statute where there is reason based in the Constitution for not observing the statutory limitation."). 


\section{The Court's Role in Creating A Substantive Framework For Resolution}

If the mediation order in the Ohio school finance litigation had come earlier in the litigation ${ }^{194}$ and had set forth a fall-back remedial procedure, it would have delivered the matter to the mediator with better prospects for generating motivation to settle than did the mediation order that was entered in 2001. 195 Better timing and a fall-back procedure alone, however, are not the only factors affecting party motivation that are within the court's sphere of influence and responsibility. A court order referring a case to mediation ought to create a substantive remedial framework that is neither too specific nor too general-a substantive framework that allows and encourages the participants to find their own resolutions to the difficult issues raised in school finance cases. The framework for decision should provide the normative parameters for resolution and at the same time leave room for creative problem solving. Professor Sturm points out, "[a]lthough these normative parameters do not provide the basis for selecting among the remedial alternatives designed to realize the liability norm, they do define the remediation norm as both the driving force and constraint of the deliberative process." 196

In referring a case to mandatory mediation, the court's task is to walk a tight-rope. It ought to define the risk of non-settlement and remedial norms, but leave options open to permit the parties flexibility in choosing a resolution that meets their needs and interests. The court must give sufficient guidance, but leave a realm of ambiguity to motivate the parties to formulate a remedy of their own.

The mediation process is not the appropriate forum for the formulation of the substantive liability norms or the basic remedial norms. Professor Lawrence Susskind, a well-known scholar of alternative dispute resolution processes, makes a distinction "between disputes about rights (whether or not something ought to be done) and disputes about how to do something, given that there is agreement that it ought to be done. Consensus building processes," he says, "can be used to help with the second type of dispute but

194 As noted above, a logical time to send the case to mediation might have been after the legislature's first failed attempt to enact remedies to cure constitutional violations. See generally DeRolph II, 728 N.E.2d. 993 (Ohio 2000).

195 DeRolph Mediation, 758 N.E.2d 1113, 1116 (Ohio 2001).

196 Sturm, supra note 8, at 1429. 
not the first."197 The power and authority to declare the constitutional rights of the parties is properly the task of the court; as the "articulator[] and guardian[] of constitutional values."198 Particularly in cases involving the ideals of equal justice, the court must play an important role that a consensus building process cannot. As Professor Richard Abel points out, "[l]aw is the sole arena within which unequals can hope to achieve justice. Only equals can risk a confrontation within the informal processes of the economy and the polity."199

Left to their own devices, legislatures and executive agencies, even if they acknowledge the existence of inequities or inadequacies, are not likely to provide meaningful relief, since they tend to be answerable politically to the established power interests that benefit from the status quo. Thus, once a constitutional value has been identified, it is the courts that must initiate and sustain an effective colloquy. In doing so, the courts should provide the legislative and executive branches with clear guidelines on expected directions and a workable framework for organizing and monitoring the results ... 200

Within the context of a consensus building process, a well-articulated statement of rights and remedial principles acts to counterbalance the power of the parties representing the status quo, placing the parties on more closely equal footing. It establishes a framework for discussion without inappropriately attempting to decide the details of implementation. ${ }^{201}$ It empowers the parties to devise their own resolution, and, with the continued participation of the court in the process, serves to motivate them to move toward resolution.

197 Lawrence Susskind, Resolving Public Disputes, in Negotiation: STRATEgIES FOR MUTUAL GaIN 61, 66 (Lavina Hall ed. 1993). But see Rebell \& Hughes, supra note 11 , at 124.

198 Rebell \& Hughes, supra note 179, at 1152.

199 GOLDBERG ET AL., supra note 68, at 175 (quoting Richard Abel, Informalism: A Tactical Equivalent to Law, 19 CLEARINGHOUSE REV. 375, 383 (1985)). But see Freeman \& Langbein, supra note 70, at 10814 (smaller, less powerful groups participating in negotiation of environmental regulations did not find that larger, more powerful groups enjoyed disparate influence over outcomes).

${ }^{200}$ Rebell \& Hughes, supra note 179 , at 1146-47.

201 In addition to providing a favorable context for creative problem solving, an order that allows the participants to devise the remedial details would capitalize on the unique competencies of the participants and accommodate, to some degree, for separation of powers concerns. 
In the DeRolph case, the mediation was required to go forward in the absence of a clear statement of rights and remedial principles. The court had issued opinions in March 1997 and in May of 2000, either of which would have served as a sufficient guiding document for a mediation process. ${ }^{202}$ In its 1997 opinion, the court held the state's statutory school finance scheme to be unconstitutional, identified aspects of the school funding scheme that required change, and established benchmarks for any new funding scheme that might be devised. ${ }^{203}$ Again, in May 2000 the court articulated the constitutional values involved and attempted to give substance to the concept of a "thorough and efficient" public education." 204 By the time the court referred the case to mediation, however, the clarity of the principles involved had been significantly undermined - if not totally uprooted-by the DeRolph III compromise decision. The decision appeared to yield to political resistance to its earlier orders, backing down from its earlier finding that a funding system based primarily on local property taxes was constitutionally defective. ${ }^{205}$ Worse, however, than the apparent concessions on earlier declared principles, the court failed to enunciate any new principles to explain its resolution of the issues. Moreover, although the court's compromise did not state new principles or reasons sufficient to justify its conclusions, it did choose to "split the baby" in a very specific way. The DeRolph III decision provided a very specific remedy-the inclusion of different factors in certain funding equations, and full funding of other provisions. ${ }^{206}$ The decision was intended to end debate, not to serve as a framework for continued discussion. When it became apparent that the decision to split the baby did not end debate because the numbers it was based on were incorrect, the case was referred to a mediator in a context where one might appropriately assume that the only issue to be decided was: "How can we adjust the existing funding formulas in a way that will result in a financial resolution closest to the one that the court intended in the DeRolph III decision?" This very narrow question does not lend itself well to creative thinking about options and the generation of win-win solutions. ${ }^{207}$

202 See generally DeRolph I, 677 N.E.2d 733 (Ohio 1997); DeRolph II, 728 N.E.2d 993 (Ohio 2000).

203 See supra text accompanying notes 90-94.

204 See supra text accompanying notes 116-20.

205 See supra text accompanying notes 138-49.

206 See supra text accompanying notes 141-48.

207 Professor Nancy Welsh argues that mediation most often results in distributive rather than "win-win" settlements. See Nancy A. Welsh, Making Deals in CourtConnected Mediation, 79 WASH. U. L.Q. 787, 813 (2001). Even if creative settlements do 
Justice Douglas, in his concurring opinion to the order referring the case to mediation, expressed his view that the mediator could consider not only the matters raised in the State's motion to reconsider, but also any other issues in the case, including a complete systematic overhaul of the state's school funding system. ${ }^{208}$ It seems unlikely, however, that once a majority of the court had endorsed the basic provisions of a school-funding scheme (as the court did in DeRolph III) that the state would agree to consider any remedy that would fundamentally alter those basic provisions. Thus, the DeRolph III decision substantially impaired the ability of the parties to fashion their own remedy, depriving the mediation process of its greatest potential.

\section{B. Identifying and Including Stakeholders}

In convening any mediation, the first obligation of a successful mediator is to make sure that all of the stakeholders in the conflict have been identified and are either present at the table or are represented in the process. ${ }^{209}$ Lengthy discussions and difficult compromises will count for nothing if at the end of the day parties who were not involved in the process appear and decide to oppose implementation of the resolution. The experience of the effort to resolve an Alabama school funding case using a facilitated settlement process is instructive on this point. There the Circuit Court of Montgomery County entered an order finding that the system of public education in Alabama was unconstitutional and directed the legislature to develop a comprehensive remedy plan with the assistance of a courtappointed facilitator. ${ }^{210}$ Over the period of the next several months plaintiffs

not result from mediation, however, she argues that mediation must provide the participants with the opportunity to explore options, to tell their stories, and to gain the experience of procedural justice. $I d$. at 855 . The brainstorming and mutual re-education that occurs in a process with possibilities for a variety of remedial options is valuable, even if a "win-win" solution is not the outcome. Id. at 858-59.

208 DeRolph Mediation, 758 N.E.2d 1113, 1120 (Ohio 2001) (Douglas, J., concurring).

209 SUSSKIND \& CRUIKSHANK, supra note 177 , at 101 (productive negotiations cannot begin until stakeholders are identified and represented); J.B. Ruhl, Thinking of Mediation as a Complex Adaptive System, 1997 BYU L. REV. 777, 788 ("[B]asic mediator training instructs that a mediator should look for issues that require other participants for full resolution and then ask the mediating parties whether that is not the case.").

210 Pinto v. Alabama Coalition for Equity, 662 So.2d 894, 897 (Ala. 1995). Initially, the legislature resisted and sought an advisory opinion from the Alabama Supreme Court that would declare that the legislature was not under any duty to comply with the Circuit 
and defendants worked together with the facilitator and devised a comprehensive remedial plan. ${ }^{211}$ All of the participants in the case were satisfied with the plan, which would be implemented subject to the court's approval following a "fairness hearing." 12 Two days before the scheduled fairness hearing a group claiming to represent "taxpayers and citizens of Alabama" moved to intervene and to oppose both the finding of liability and the proposed remedial plan. ${ }^{213}$ Although the Circuit Court denied the petitions to intervene, the interveners were ultimately successful in derailing the settlement process. ${ }^{214}$

The participation of all of the stakeholders, particularly those who will cause trouble - that is, those who may oppose or thwart the implementation of any eventual resolution of the dispute-is essential to the process. ${ }^{215}$ Gaining the assent of the most vocal activists and the most difficult opponents of reform is key to the successful implementation of the remedy. Although the involvement of stakeholders is central to the mediation, the process by which the interested stakeholders are identified and integrated, either individually or through representatives, is not uniform. It has been described as an "art." 216

School finance reform presents a stakeholder palette that would challenge even the most skillful mediation artist. When Ohio Governor Bob Taft devised a list of the groups that he believed "are involved in the school funding debate in one way or another," the list included important governmental actors, state agencies, and dozens of professional associations

Court order. See Opinion of the Justices, 624 So.2d 107, 110 (Ala. 1993) (holding that the legislature was required to comply with the Circuit Court order.)

211 See Pinto, 662 So.2d at 897.

212 Id.

213 Id. Michael Rebell describes the intervenors as "a number of religious and parent groups who asserted that they had been excluded from the decision-making process." Rebell \& Hughes, supra note 179, at 1157.

214 In Pinto, the Supreme Court heard the petitions to intervene and decided that the taxpayer group was entitled to intervene in the remedial phase of the litigation. 662 So.2d at 899 . In later proceedings the Alabama Supreme Court dismissed the case, holding that the issue of school finance was a non-justiciable political question. See generally Ex parte James, 2002 WL 1150823 (Ala. May 31, 2002).

215 HALL, supra note 165 , at 35 .

216 Interview with Professor Douglas H. Yarn, in Atlanta, Ga. (Sept. 6, 2002). The process may vary according to the particular mediator and the particular dispute. Common practices are described in SUSSKIND \& CRUIKSHANK, supra note 177, at 10108. See also CARPENTER \& KENNEDY, supra note 71, at 168-75 (2001) (discussing how various constituencies may be represented and involved in the resolution of a public dispute). 


\section{COURT-ORDERED MEDIATION IN SCHOOL FUNDING}

and private citizens groups. ${ }^{217}$ The challenge of engaging and involving large numbers of interested parties in a public policy mediation, however, is one that skilled mediators have faced repeatedly and have successfully addressed. ${ }^{218}$ Consensus-building processes have been used to resolve a wide variety of public policy issues and disputes. ${ }^{219}$ Issues of representation and

217 See "Building Blocks, An Ohio School Funding Resource," at http://www.ohioschoolfunding.org/resources/index.asp (last visited Sept. 15, 2002). The list of interested actors and groups included the following: (governmental actors) Governor Bob Taft, Ohio Department of Taxation, Ohio General Assembly; (State agencies) Office of Budget and Management (OBM), Ohio Department of Education (ODE), Ohio School Facilities Commission (OSFC), Ohio SchoolNet Commission; (professional associations) American Association of Retired Persons, American Federation of State, County and Municipal Employees, Association of Christian Schools International, Buckeye Association of School Administrators (BASA), Catholic Conference of Ohio, Children's Defense Fund of Ohio, Cincinnati Federation of Teachers, National Alliance of Black School Educators, National Federation of Independent Businesses-Ohio, National Governor's Association (NGA), National Middle School Association, Ohio Association for Gifted Children, Ohio Association for Supervision and Curriculum Development, Ohio Association of Child Care Agencies, Ohio Association of Elementary School Administrators, Ohio Association of Pupil Services Administrators, Ohio Association of School Business Officials (OASBO), Ohio Association of Secondary School Administrators, Ohio Association of Supervisors and Work-Study Coordinators, Ohio Chamber of Commerce, Ohio Education Association (OEA), Ohio Farm Bureau Federation, Inc., Ohio Manufacturers Association, Ohio Middle School Association, Ohio School Boards Association (OSBA), Ohio School Counselors Association, Ohio School Psychologists Association, Ohio AFL-CIO, Ohio Vocational Association, The Ohio Public Expenditure Council, KnowledgeWorks, Education Tax Policy Institute; (Private Citizens Groups) Coalition of Rural \& Appalachian Schools, League of Women Voters of Ohio, National Taxpayers Union, Ohio Coalition for Equity \& Adequacy of School Funding, Ohio Coalition for the Education of Children with Disabilities, Ohio Coalition of Essential Schools, Ohio Congress of Parents and Teachers, Ohio Roundtable, Ohio Taxpayers Association, The Buckeye Institute, The New Ohio Institute, Americans for Tax Reform.

218 Robert Zeinemann, The Characterization of Public Sector Mediation, 24 ENVIRONS ENVTL. L. \& POL'Y J. 49, 53-54 (2001) (asserts that mediation is increasingly used to resolve public disputes and suggests some reasons why).

219 See, e.g., Freeman \& Langbein, supra note 70, at 10811; Policy Consensus Initiative, Governing Tools for the $21^{\text {st }}$ Century: How State Leaders Are Using Collaborative Problem Solving and Dispute Resolution (2002) (describing existing programs using consensus building processes to resolve public disputes in 12 states); GOLDBERG ET AL., supra note 68, at 485-511 (describing the use of ADR processes to resolve disputes of public importance). 
management of the process, while complex, are nevertheless familiar and can be successfully managed by a skillful mediator or team of mediators. ${ }^{220}$

On the other hand, litigation pending in court is not typically held open for public participation.221 Including the interested constituencies in mediating a school finance lawsuit would require a process that would reach beyond the litigants named in the action. Involving various non-litigant members of the public in the remedial process of pending litigation concerning constitutional rights with broad impact is not unprecedented. ${ }^{222}$ Including non-litigants in court-ordered mediation may, in fact, be widely practiced with the consent of the litigating parties. Using an inclusive, consensus-building process at the intersection of public-policy facilitation and private litigation may be a common mode of dealing with litigation that has broad public impact, but the practice is not generally documented.

To be clear, the process I envision would not be "open to the public" in the common sense of that expression. Rather, interested groups would be identified by the mediator or team of mediators, who would choose representatives and would form sub-groups or coalitions based on their areas of interest or expertise. The mediator, in consultation with the litigating parties, would control the size and composition of the participant group. ${ }^{223}$ While the prospect of identifying representatives from an almost unlimited group of interested stakeholders may appear daunting, in fact, the time commitment and real work obligation of a mediation process acts to limit the

220 SUSSKIND \& CRUIKSHANK, supra note 177 , at 37.

221 See FED. R. CIV. P. 24(a) (Intervention of Right); OHIO R. CIV. P. 24(a) (Intervention of Right).

222 See, e.g., Pottinger v. City of Miami, 76 F.3d 1154 (11th Cir. 1996) (directing parties to meet to settle the case); Kathy Glasgow, The City of Miami's Court-Approved Plan to Deal with the Homeless, MIAMI NEw TIMES, Dec. 24, 1998 (describing the resolution of a civil rights action involving the rights of the homeless population of the City of Miami that required the participation of homeless advocates, city officials, neighborhood organizations, shelter personnel, police and others).

223 After the stakeholders have been identified and have been convened, the next task of the mediator is to empower the participants so that they own the process from the very beginning. The participants should plan the process: They should agree on a timetable and a process design that would include information exchange, generation of alternative solutions, evaluation, decision-making and implementation. The resulting scheme may require the commitment of a full-time process manager and may require more than a year of work. See HALL, supra note 165, at 37. The Court should permit the mediator to be flexible in working with the parties over an indefinite period to attempt to achieve a resolution. On the other hand, periodic progress reports to the Court must be required to ensure that one or several of the parties are not dragging their feet to avoid implementation of any remedy. 
participants to those whose interest in the outcome is substantial. ${ }^{224}$ The participants will be, in a sense, self-selected. Further, if sheer numbers of participants prohibits productive discussions, the mediator may use several strategies for managing the work without excluding participants. ${ }^{225}$ While the mediation may take longer and be more difficult to manage with the inclusion of a large number of participants, the inclusion of those participants will ensure the success of the any settlement that may ultimately be reached.

Involving a broad range of interested constituencies in an effort to resolve school finance issues simply makes sense. Consensus building processes have been used successfully in a wide range of school disputes. ${ }^{226}$ Further, the kind of wide-ranging reform required in a school finance case may not be possible to implement without broad-based public support. ${ }^{227}$ Moreover, the major litigant named in the lawsuit, the General Assembly, is not an individual, but a public body. Members of the General Assembly represent diverse constituencies and are subject to conflicting pressures exerted by various interest groups, activists, and lobbying organizations. ${ }^{228}$ Elected officials must, to a large extent, guess about the priorities of their constituents. Members of the General Assembly might be loath to make a

224 See HALL, supra note 165 , at 35.

225 See CARPENTER \& KENNEDY, supra note 71, at 100-36 (discussing strategies, procedures and ground rules for managing public policy disputes).

${ }^{226}$ See, e.g., Amy Totenberg, "Use of Special Masters in Complex Litigation," JAMS ATLANTA NEWSLETTER 1 (Spring 2002) (describing mediation of standards for disengagement in a case involving special education); Rebell \& Hughes, supra note 11, at 114-36 (proposing a community dialogic model for resolving conflict relating to school reform).

227 Jonathan R. Werner, No Knight In Shining Armor: Why Courts Alone, Absent Public Engagement, Could Not Achieve Successful Public School Finance Reform In West Virginia, 35 COLUM. J. L. \& SOC. PROBS. 61, 62-63 (2002) ("The kind of sweeping change the decision envisioned required broad support for the court's action through a coordinated, multi-faceted effort targeted at garnering the support of legislators, taxpayers, school districts, and other key players.").

228 There is, of course, a rich literature examining the legislative decision-making process. See generally Jerry L. Mashaw, GreEd, ChaOs, AND Governance (1997); Daniel A. Farber \& Philip P. Frickey, Law And Public Cholce: A Critical Introduction (1991); Dwight R. Lee, Politics, Ideology, and the Power of Public Choice, 74 VA. L. Rev. 191 (1988); Daniel A. Farber, Democracy and Disgust: Reflections on Public Choice, 65 CHI. KENT L. REV. 161 (1989). But see Cass R. Sunstein, Beyond the Republican Revival, 97 YALE L.J. 1539, 1550-52 (1988) (describing modern civic republican thought that is characterized by a commitment to values-oriented deliberation in politics, rather than horse-trading). I do not hope here to undertake an analysis of influences on legislators as they deliberate, horse-trade, or follow their consciences in making legislative choices. 
concession during a mediation in an area in which they perceive themselves to be politically vulnerable, especially if core constituencies have expressed opposition to making concessions prior to the mediation. ${ }^{229}$ Elected officials left to work toward a mediated solution in a closed process are, in essence, subject to the same pressures that created the already existing unconstitutional legislative scheme. In contrast, if the mediation process is open and its boundaries permeable, various individual interest groups can be allowed to express their points of view for themselves. Stakeholders who are present and involved can be encouraged through the process to understand the views of other parties, and can be encouraged to work toward collaborative solutions. In face-to-face problem solving sessions, stakeholders may be heard and their priorities may be realistically assessed and reordered. ${ }^{230}$ The participation of a wide variety of interested groups would allow legislators to change their positions with the assurance that their constituents have considered the options and have been persuaded of the wisdom of the new solution. Finally, the process may provide a scapegoat for the legislature, allowing representatives to avoid taking political heat for changed positions or controversial votes. ${ }^{231}$

In its order referring the Ohio school finance case to mediation, the Supreme Court identified the plaintiffs, and the defendants-members of the Ohio General Assembly, the Ohio Board of Education, the Ohio Superintendent of Education, and the Ohio Department of Educationthrough their counsel, as the participants in the process. ${ }^{232}$ The court further invited Governor Bob Taft, through counsel, to participate as a party for "purposes of the settlement conference." ${ }^{233}$ These parties were, it appeared, the minimum necessary for any potentially binding settlement. Nevertheless, the State challenged the court's identification of the parties to be included in the mediation, objecting specifically to the designation of the Attorney General as counsel to represent the State and to the participation of the amici counsel, who represented minority party members of the General

229 Public choice theorists examining legislative process view legislators as rational bargainers who are motivated by a desire to be re-elected. See generally supra note 212 .

${ }^{230}$ CARPENTER \& KENNEDY, supra note 71 , at 18-52 (describing methods for group problem solving and alternative approaches to managing conflict).

231 See Frank M. Johnson, Defending Constitutional Rights, 20-21 (Tony Freyer, ed., 2001) (describing how the federal courts provided a scapegoat for political actors who could not publicly support desegregation of southern facilities).

232 DeRolph Mediation, 758 N.E.2d 1113, 1116-17 (Ohio 2001).

233 Id. at 1117. 


\section{COURT-ORDERED MEDIATION IN SCHOOL FUNDING}

Assembly. ${ }^{234}$ The Supreme Court rejected the State's arguments, pointing out that the defendants had consented to the participation of the identified attorneys throughout the life of the litigation. ${ }^{235}$ The court further pointed out,

Experience has demonstrated that a satisfactory result is fostered in publicpolicy mediations as-contrasted with private dispute mediations involving individuals-by including representatives expressing the full range of competing interests. ${ }^{236}$

In the Ohio school finance case, the court may have intended to permit the mediator to do the hard work of identifying the stakeholders and convening an inclusive process, but its order setting up the mediation did not express a vision of a broad-based, participatory process. The order appointed a single mediator and allowed for an initial six weeks to attempt to settle the case. The mediator faced immediate opposition to including even the parties who had participated in the litigation during the previous ten years. In this context, it may have been impossible to convene anything but the most constrained and limited group. If, on the other hand, the court had-early in the remedial phase of the litigation-entered a mediation order that appointed a team of mediators, that encouraged or required the parties to involve and include interested non-party stakeholders, and that set up generous time-frame, the important work of including the interested parties could have been done.

\section{CONCLUSION}

Following the failure of the DeRolph mediation, the Ohio Supreme Court granted the State's motion to reconsider the DeRolph III decision. ${ }^{237}$ Vacating DeRolph III in its entirety, the Court returned to the reasoning and the result of the DeRolph I and DeRolph II decisions. ${ }^{238}$ Once again, the Court held that the legislature had not fulfilled its Constitutional duty to

234 DeRolph v. State, 760 N.E.2d 351, 352-54 (Ohio 2001)

235 Id. at 353.

236 Id. at 355.

237 DeRolph IV, 780 N.E.2d 529 (2002).

238 Id. The decision on the motion for reconsideration resurrected the fourmember majority of the DeRolph I and DeRolph II decisions. Justice Pfeifer, who had joined the DeRolph III majority, returned to his earlier position and wrote the opinion for a majority that included justices Resnick, Sweeney and Douglas. Id. at 529. 
provide a "thorough and efficient system of common schools." 239 And, once again, the Court gave no specific guidance to the legislature as to how to enact a constitutional school funding system beyond reiterating that a "complete systematic overhaul" of the school funding system is needed. 240 The remedy in the DeRolph case remains to be devised. ${ }^{241}$ Further litigation relating to the remedy is likely.

School finance cases present difficult, complex, and seemingly intractable remedial issues. Litigation and its traditional remedial processes provide an unsatisfactorily blunt tool for the task of re-designing a complex school funding system. ${ }^{242}$ Mediation, on the other hand, may be the device that is most ideally crafted for the job. Mediation as a process holds promise for resolving school finance reform litigation because it can provide a flexible procedure that may address the needs for the participation of a diverse and large number of constituencies; technical expertise and forwardlooking decision-making about complex issues; and consensus-building that will facilitate the cooperation among the various public entities involved in implementing the remedy. Mediation could lead to qualitatively superior solutions, through the information-sharing and mutual education involved in face-to-face negotiation sessions. (Certainly, the embarrassment of DeRolph $I I$-in which the court based its decision on incomplete budget numberscould have been avoided if the state parties had been involved in making the remedial calculations. ${ }^{243}$ ) A mediated process could give various constituencies an opportunity to participate in the development of the remedy, and thereby contribute to the legitimacy of the eventual solution. Mediation could also contribute to the stability and long-term success of the school reform remedy by creating grass-roots support for implementation of the remedy and by creating avenues of communication among the various interested parties. Even after the failure of the mediation effort in this case,

$239 \mathrm{Id}$. at 530.

$240 \mathrm{Id}$. at 533 . In this author's view, in failing to devise a remedial procedure to enforce the finding of a constitutional violation, the court has side-stepped an important constitutional duty. The court ought not abdicate its responsibility to the plaintiffs because of the difficulty of devising a remedy. See Sturm, supra note 8, at 1379 (discussing the theory of the court's remedial power).

241 As Chief Justice Moyer pointed out in his dissent, the majority said "nothing concerning enforcement of its reaffirmed declaration that the current school-funding system is unconstitutional. It neither retains jurisdiction nor remands the cause to the trial court." Id. at 537 (Moyer, C.J., dissenting).

242 See supra text accompanying notes 43-64.

243 DeRolph III, 758 N.E. 2d 1113, 1120 (Ohio 2001); see also supra notes 130-33. 


\section{COURT-ORDERED MEDIATION IN SCHOOL FUNDING}

comments made by the mediator, Howard S. Bellman, indicated that he believed that mediation was, perhaps, a viable avenue for resolution of the case.

There is never a time when education policy is all done. Education policy is dynamic, and the environment in which it exists-the economy, the technology, the expectations that society has of the schools-all those shift around, and education has to adapt. Are you going to have a court tell you the answer every week? The real question is how will these controversies be handled? By warring camps in adversarial roles or by a consensus seeking, congenial process? ${ }^{244}$

Mediation was not the wrong answer in this case. Instead, the mediation-as ordered-was too much, too little, too late. It was too much constricted by the court's compromise on the remedy. ${ }^{245}$ It was too little supported by clear statements regarding the rights and remedial principles that should have guided the mediation process and therefore generated too little motivation to settle. ${ }^{246}$ Finally, by the time mediation was ordered it was too late, because the court's authority to give guidance on the matters that might have put an effective mediation process in motion had been seriously impaired by the compromise decision of September 2001.247

In vacating the compromise DeRolph III decision, however, the Court may have provided itself and the parties with a new window of opportunity. It may not be too late after all. The parties may now voluntarily engage in a facilitated negotiation process to effect the implementation of a constitutionally sound public school funding system. Alternatively, if the parties return to court in the future, the court will have a new opportunity to structure a participatory remediation process that is designed for success.

The lesson of the DeRolph case is not that court-ordered mediation cannot contribute to the successful resolution of difficult institutional reform litigation. Rather, DeRolph teaches that mediation is more likely to play a positive role in the resolution of an important institutional reform case if it is considered as a primary avenue of achieving remedial results rather than as a very last resort. Further, any court considering whether to order the mediation of an important institutional reform case should be attentive to creating a substantive and procedural framework that will support the parties'

\footnotetext{
244 Editorial, The Last Word, Columbus DisPatCH, Mar. 24, 2002, at D2.

245 See supra text accompanying notes 113-23.

246 See supra text accompanying notes 152-63.

247 See supra text accompanying notes 114-22.
} 
motivation and effort to devise their own remedy. The court should also consider the legitimacy benefit that may accrue from the participation of a broad group of interested constituencies and construct a framework that supports the mediator's efforts to identify and include stakeholders. Supported by a clear and unequivocal statement declaring the rights of the parties and remedial principles and a mediation order outlining fall-back remedial procedures that will be implemented if resolution is not achieved and creating incentives to permit participation by a broad range of nonlitigant stakeholders, future institutional reform mediations need not fail. 